\title{
Buddhist Homiletics on Grief
}

( ${ }^{*}$ Saddharmaparikathā, ch. n)

\author{
Péter-Dániel Szántó | ORCID: 0000-0001-7445-533X \\ Universiteit Leiden, Leiden, The Netherlands \\ p.d.szanto@hum.leidenuniv.nl; szantopeterdaniel@gmail.com
}

\begin{abstract}
The study first introduces a hitherto completely unstudied anonymous work, for which I reconstruct the title *Saddharmaparikatha . This substantial text is a Buddhist homiletician's guidebook with sample sermons in Sanskrit on a rich variety of topics. I argue that it dates from the $5^{\text {th }}$ century and that it was possibly authored in a Sammatiya environment. I first discuss the unique manuscript transmitting the text, the structure and contents of the work, what information it can provide for the tradition of preaching and its importance for Buddhist studies. In the second half, I provide a sample chapter 'On Grief' with an annotated translation.
\end{abstract}

\section{Keywords}

Buddhist literature - Buddhist homiletics - Sanskrit manuscripts - grief - preaching

\section{In memoriam Stefano Zacchetti}

Latiatuc feleym zumtuchel mic vogmuc. ýfa pur ef chomuv uogmuc.

"See what we are, brethren? We are but dust and ashes." Sermo super sepulchrum in Old Hungarian (The Pray Codex, ca. 1192$1195 \mathrm{CE}$ ) 
The *Saddharmaparikathā or "Sermons on the True Law" is a Buddhist homiletician's guidebook composed probably around the 5 th century CE. The work survives in a single manuscript, which was penned somewhere in Magadha, possibly during the first half of the 11th century CE. While the copy seems to be complete in fifty-seven large-format palm-leaf folios, it does not transmit a colophon, and thus neither the original name of the work nor the name of the author are known. It is not unlikely that the work was left incomplete by the author himself.

The manuscript in question (henceforth Ms) was kept in Tibetan custody for possibly as long as nine centuries, but it was apparently never translated or even engaged with until modern times. The artefact was discovered for modern scholarship by Rāhula Sānkrrtyāyana (1893-1963) and Dge 'dun chos 'phel (1903-1951) in 1934, during a somewhat hurried visit to Spos khang monastery in Gtsang province. ${ }^{1}$ The famous Indian scholar was able to study it for a short time during a subsequent trip, enough for a brief scholarly report, which was published in $1938 .^{2}$ This is what he says in the introductory part of the said report:

In my second trip to Tibet, I visited the monastery of Pökhang [i.e., Spos khang] where I saw three bundles of Sanskrit Mss. in which I noticed an important work by the great poet Aśvaghôsa. My visit was so brief that I could not go through the whole work. Last time, [i.e., on his third journey to Tibet] I tried my best to visit Pökhang, but I could not go. This time I reached Pökhang on the 27th June [1938]. When the three volumes were brought, I found that one was Tridaṇdamālā by Aśvaghôsha with a separate work named Parikathā by a later author. They are not poetical works,

1 A short history of the monastery and an evaluation of its importance is provided by Tucci (1949: 201-204), and more recently by Heimbel (2013: 209-213). Spos khang was founded in 1213 ce by Byang chub dpal bzang po, a disciple of the famous Kashmiri master, Sākyaśrībhadra (for whom see Jackson 1990 and van der Kuijp 1994; the monastery was famous for housing some of his personal effects). The original site was abandoned and the monastery was reestablished at its present location (Lat. N 29.133333, Long. E 89.366667).

2 Sānkkrtyāyana 1938: 139 (the passage cited here), 16o-162 (a brief codicological note and a somewhat hurried transcription of the incipit, some of the chapter headers, and the explicit). For a more detailed description of these visits, see his Hindi biography-cum-travelogue, Sānkṛtyāyana 1994 [1998]: 173-174, 298. While this account is much more colourful and informative, it is also fraught with imprecisions. The initial visit is described very briefly in his scholarly report, see Sānkkrtyāyana 1935: 25-26, 28. 
but their importance is great, since they deal with the art of eloquence. In fact, they are practical lessons to the students of those days who wanted to become good speakers. The first work by Aśvaghôșa is rather more primitive, but the later work is far advanced, which shows that since the time of Aśvaghôșa (1st century A.c.) up to the 8th century when probably this second work was composed the art of public speech was greatly developed.

His learned Tibetan companion left some short but relevant notes in his Gtam rgyud Gser gyi thang ma (composed mostly between 1934-1941). Here the manuscript is referred to as Yongs kyi gtam, or "Great Sermon" and it is claimed that it had a note at the bottom of a folio, which had the inscription bhikșudipamkarasya pustakam, i.e., "the monk Dīpamkara's book."3 As already pointed out by Kano, this note is not preserved in the photographs we now have, and he is probably right in agreeing with Dge 'dun chos 'phel that the Dīpamkara mentioned here is none other than Dīpaṃkaraśrijñāna, a.k.a. *Adhīśa/ ${ }^{*} A t i ̄ s a / * A t i s ́ a$ (982?-1054). A more thorough palaeographical study is needed to determine whether the writing is consistent with an early- or mid-11th century environment. For the time being I accept the above hypothesis.

Sānkṛtyāyana is well-known for his diligent photography of the precious sources he had found in Tibet, and the tone of his report suggests that these were the kind of works that he would have had archived without a second thought. However, it is unclear what happened to the photographs of the manuscript or whether it had been photographed at all. While I do not have access to the Patna collection, I could consult the so-called Göttingen copies, but these turned out to be simply another print of a set of photographs taken by the next explorer who visited Spos khang, Giuseppe Tucci (1894-1984). ${ }^{4}$

3 Kano 2016: 95, Matsuda 2020a: 28 . Also see Jinpa and Lopez 2014: $36-38$, although the translation of the passage is problematic.

4 For a catalogue of the Göttingen collection (in the Niedersächsische Staats- und Universitätsbibliothek), see Bandurski 1994; the manuscripts in question are described on pp. 79-80 (Xc 14/42-42a). This set is not in any way better than Tucci's and in fact it lacks some of the initial folios sides (1v, 2r, 2v, 3r, 4r, and $5 r$; here and henceforth ' $r$ ' and ' $v$ ' are used to abbreviate the recto and verso sides of folia). In a lecture given at Ōtani University in Kyōto, Tucci (1956: 14-15) stated that Sānkṛtyāyana was not able take photographs of the Tridaṇdamālā; I take this to mean that implicitly the same is true for the *Saddharmaparikathā manuscript. How Tucci's set of negatives ended up being developed once again for Sānkṛtyāyana's collection is still unclear. The mystery is compounded by the fact that in his Hindi account, Sānkrrtyaayana claims that there were photographs taken at Spos khang (Sānkrrtyāyana 1994 [1998]: 298): खेर, वहाँ से हम 27 तारीख को पोइखड् पहूँचे और 2 जुलाई तक वहीं रहे। वहाँ की पुस्तकों ओर चित्रपटों के बहुतसे फोटो लिये। "Anyhow, from there [i.e., Shigatse] we went to Pökhang on the 27th [of June] 
Tucci's expedition visited the monastery in the same decade, in 1939, and the photographs taken of the manuscript do survive. ${ }^{5}$ These are of varying quality: some parts of the folios are clearly legible, some are slightly out of focus, and some are blurred beyond recognition. However, with some practice, about $95 \%$ of the text can be made out with a degree of certainty. Unfortunately, the manuscript is now probably lost forever and the only way we can access it is through photographs taken on behalf of Tucci. ${ }^{6}$

The material support is clearly palm leaf. The folios are quite long: according to Sānkrrtyāyana, they measure 22 inches (ca. $56 \mathrm{~cm}$ ) in length and 1.75 inches (ca. $4.5 \mathrm{~cm}$ ) in width. The manuscript seems to be complete in 57 such folios, with $1 \mathrm{r}$ and $57 \mathrm{v}$ not inscribed originally. We cannot tell what kind of para-textual elements these may have contained, because they were not photographed. $5_{6}^{6}$

and stayed there until the 2nd of July. Many photographs were taken of the books and scrollpaintings held there." A possible explanation is that Tucci was simply misinformed and that Sānkṛtyāyana's negatives were damaged (unfortunately, this seems to have happened fairly often).

5 For a catalogue of this collection, see Sferra 2008. The plates containing the manuscripts are on the compact disks numbered м 3 o to 32 . The material support was $7 / 11$ negatives; the photographs were taken by Felice Boffa-Balaran; see Nalesini 2008: 93-94. I thank Prof. Francesco Sferra for allowing access to his digital scans of the pictures. For a map of where the folios edited here can be found, see Appendix 2.

6 As already pointed out by Sānkrṛtyāyana, the manuscript containing the text under scrutiny is one of a pair (or a triad, but the contents of the third bundle do not concern us here). The sibling of our manuscript contains an even longer work called the Tridandamālā, which is attributed in the colophon to Aśvaghoșa. After a very brief note by Johnston (1939), in which he dismissed the idea that the Aśvaghoșa of this text is the same as the poet Aśvaghoșa (ca. 8o-15o ce), it is only very recently that a careful study of this witness has been taken up by Kazunobu Matsuda (2019, 2020a, 2020b, 2021) and Jens-Uwe Hartmann (2020: 376-380, as well as the 8th Prof. Michael Hahn Memorial Lecture, "Doctrine, Poetry, and Ritual: Did Aśvaghoṣa Author the Tridanḍamālā?" at the Department of Pali and Buddhist Studies, Savitribai Phule Pune University in collaboration with Deshana Institute of Buddhist and Allied Studies, delivered on 12th July 2021). Also see $n$. 33. The results, to say the least, are outstanding: e.g. so far nearly two entire chapters from the lost latter half of the Buddhacarita have been recovered. While the scribal hand of the *Saddharmaparikatha and that of the Trida$n$ nqamāla are not the same, they are very similar. The size of the material support and the layout are also very similar. The foliation is, however, in a different system. Nevertheless, the similarities suggest that the two manuscripts were products of the same scriptorium, in spite of the fact that the sectarian backgrounds of the two texts seem to differ: the Tridandamála is clearly a Sarvāstivāda compilation, whereas the *Saddharmaparikathā is possibly a Saṃmatìya/Sammitìya work (see below). Moreover, at least five verses are transmitted in both texts. Unfortunately, this manuscript too seems to have fallen prey to the Cultural Revolution, during which Spos khang monastery was severely damaged. Neither of the two titles can be found in the catalogues compiled by Chinese scholars (Luo Zhao, Wang Sen, as well as some anonymous hand-lists). 
folios are meticulously numerated in the left margin of the versos with true numerical digits (i.e., not letter-numerals). The writing surface consists of three blocks, which are separated by two string-spaces left completely empty. The width of the string-spaces fluctuates between five to eight akșaras. Each folio side is inscribed with five lines of writing. Each block contains about forty akșaras, i.e., there are about 120 akssaras per line. Traditionally, the size of the work would have been given as ca. 2,10o granthas. Sānkṛtyāyana calls the script Kuṭilā, or one might say proto-Maithili-cum-Bengali. The script is not unlike that of the known Vikramaśila manuscripts, ${ }^{7}$ but it is not identical to them. The scribe commonly uses the prșthamātrā, but there are also plentiful examples of the sirrorekhā. Contrary to received wisdom, this does not necessarily mean that the hand is Nepalese.

The quality of the scribal work is very good, but not exceptional. The writing is elegant and is without doubt the work of a professional scribe, who also understood what he was copying. Spotted mistakes are meticulously corrected and there also seem to be corrections in a reader's hand. ${ }^{8}$ Unfortunately, lacking good colour images it is difficult to make out what is a second hand and what is not. In spite of the obvious care, a number of mistakes remain, most crucially the omission of entire pādas (see e.g. stt. 3.7od, Ms $15 \mathrm{r} 2$ or 3.74b, Ms 15r5) in some of the verses. Grammar, the flow of the argument, and style also suggest that there must be omissions in the prose passages, too.

The work can be best described as a practical handbook of Buddhist homiletics. It is not a theoretical guide, since it is not about the way sermons are to be constructed or delivered. Instead, the author aims to give a series of templates for the actual sermons. The work, or what remains of it in its present state, is divided into fifteen (or, better said, 1+14) major, unnumbered and untitled chapters of uneven lengths. The longer chapters are subdivided into sections, either on account of the topic or because the preacher is given dispositions ${ }^{9}$ (called kalpa, krama, vidhi, or naya) as to how to deliver the same or a similar message with a different wording or rhetorical approach (inventio). A brief outline is as follows:

7 See Delhey 2015 .

8 If the manuscript did indeed belong to Dīpamkaraśrijñnāna/*Adhīśa/*Atiśa/*Atiśa, there is a tantalising possibility that some of the corrections are in the famous Bengali master's hand.

9 I borrow this term (and several others) from the tradition of Christian homiletics: the word dispositio is known as $\tau \alpha \dot{\xi} \xi \varsigma$ in Greek rhetorics. I benefitted greatly from the "Silva Rhetoricae" project's excellent resource for homiletical terms, which can be found here: http://rhetoric .byu.edu. 
[1] (Ms 1v1-1v4) Introductory statements in twelve verses. The author briefly outlines his aims and modus operandi. ${ }^{10}$

[2] (Ms 1v4-9ri) On refuge, or the merits of converting to Buddhism (śaranagamanaviśeșanārtham ... parikathā) in five dispositions.

[3] (Ms 9r1-21r4) On charity, or the merits of giving, primarily to the Buddhist monastic community (dānaparikathā) in eleven dispositions.

[4] (Ms 21r4-22v3) On offering garlands to stūpas (mālyābhihāraparikathā).

[5] (Ms 22v3-34v3) On morality (śilaparikathā) in ten dispositions, where the fifth is specifically dedicated to the observance of the Poșadha, the sixth to restraint from killing, the seventh to restraint from stealing, the eighth to restraint from adultery, the ninth to restraint from sinful speech, and the tenth to restraint from drinking liquor.

[6] (Ms 34v3-36v1) On offering lamps in front of Buddhist icons, stūpas, etc. (dīpamālādhikāra).

[7] (Ms 36vi-42r5) Refutation of other systems of thought (parasamayadarśanārtham ... parikathā) in two dispositions. Following a general introduction, a variety of Brahmanical gods are criticised for their exploits, then follows a critique of some Vedic rituals and dharmaśāstra injunctions. The second disposition is more philosophical in nature: it contains a refutation of Sāṃkhya, Vaiśeșika, Digambaras, and Nirgranthas (possibly the Ājīivikas).

This highly interesting chapter would of course merit a separate study, but here I shall limit myself to a note on a single verse-pair because of its importance for the history of the genre. The third and fourth stanzas (Ms 1v1-2) read as follows:

kāmaṃ lakṣanatah proktạ̣ pūrvācāryair ayam vidhih |

tāvatā tu na sarvaḥ syāt kartuṃ parikathām prabhuh \|

yat tv (em., yatv Ms) adhītyaiva śaktah syāt parișac(em., parșac $\left.{ }^{\circ} \mathrm{Ms}\right)$ cittakalyatām | samādhātum akṛchrena tan mayā racayișyate \|

"Granted, this method has already been taught by previous masters (/the venerable master of yore) via their short indications (lakșanatah); however, not everyone will become able to deliver sermons by only that much. I, on the other hand, shall compose such [a treatise], after the study of which one will immediately and with little effort become able to cause a mental receptiveness (cittakalyata $\overline{)}$ in the audience."

It seems that the entire pre-history of the homiletical genre hinges on our interpretation of the word lakșanatah. There is a strong possibility that what our author means to convey by this word are not 'definitions', but the short introductory or concluding passages framing Āryaśūra's Jātakamālā, a work that, as will be demonstrated below here, was a fundamental influence. Meiland (2009: xxii-xxiii) refers to these as 'maxims' and 'epilogues'. If this interpretation is correct, it would mean that the author is consciously developing a new genre (to wit, sample homilies) which was hitherto present only rudimentarily in his intellectual world. A second problem is how to understand pūrvācāryair: it might be an actual plural or a plural of respect (possibly for Āryaśūra). 
[8] (Ms 42r5-45v3) On icons, or on the virtues of creating and maintaining Buddhist images (tathāgatapratimācitrayituḥ saṃharșaṇārtham parikath $\bar{a})$ in two dispositions.

[9] (Ms 45v3-5) On erecting and honouring a stūpa (stūpasatkārādhikāra). ${ }^{11}$

[10] (Ms 45v5-49r3) On refuting accusations of barbarism, i.e. incorrect linguistic usage (apaśabda) in seven dispositions.

[11] (Ms 49r3-53r2) On grief, or on the futility of mourning (śokavinodanārtham ... parikathā) in three dispositions. This is the chapter discussed here.

[12] (Ms 53r2-54r3) On gambling, or on the evils of dice-playing (dyūtādinavapradarśana).

[13] (Ms 54r3-55v2) On bathing at sacred fords, or, more exactly, on the futility of this heathen custom (tīrthābhișekaparīkșā).

[14] (Ms 55v2-57r1) On self-immolation and other such customs people consider to be acts of faith (agnipraveśädidharmaparīkșā).

[15] (Ms 57r1-5) On the futility of fasting (anaśana).

Judging by the number of words dedicated to these topics, the reader's first impression is that the primary concerns of the author seem to have been strengthening devotion in the already Buddhist community and converting Brahmanical laity (chs. 2, 7, 13, 14, 15), assuring charity to the Sangha (ch. 3), and the observation of morality (chs. 5,12 ) and decorum (ch. 11). Less space is given to praising external displays of devotion (chs. 4, 6, 8, 9), which nevertheless remains an important topic. Perhaps the most remarkable (and possibly even unique) passage is the one in which the preacher is instructed how to address accusations of improper linguistic usage (ch. 9).

The work ends rather abruptly, discussing the futility of fasting. I find it highly unlikely that an author writing a work of this calibre would have left off without as much as the customary dedication of merits. We must therefore presume that the *Saddharmaparikatha was never finished. Alternatively, one might posit that given the venerable age of the text (see below), it was transmitted only in part already by the 11th century. Third, it is also possible that

11 Given the importance of the stüpa-cult in the period, this passage is suspiciously short. I do not have a convincing explanation for this brevity, save perhaps that the author might have thought of the topic as sufficiently developed elsewhere (e.g. in the Prasenajitpariprcchā, see Vinītā 2010, 207-258) and therefore something that he should not dwell upon for too long. Conversely, the particular attention to frescoes in the previous chapter is noteworthy. Chapter 6 also alludes to removing the darkness in a caityagrha by lighting lamps. It is tempting therefore to think that the author was active in an environment where housed icons, perhaps in cave-shrines, were in abundance. Sites such as Ajanta immediately spring to mind. 


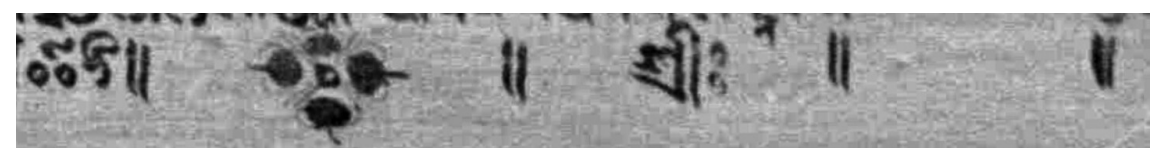

FIGURE 1 Fleuron and the auspicious syllable śrị̆ at the end of the manuscript on 57r5

the work as we have it now is an unfinished draft. The somewhat haphazard arrangement of the chapters and at least one unmatched internal reference would suggest so. ${ }^{12}$ However, all these scenarios are mere hypotheses. It is not reasonable to assume that the exemplar of our scribe was incomplete, because the text does finish rather neatly at the end of a section. Had the scribe inherited a damaged copy, it is unlikely that the lacuna would have started exactly at such a point. Nor is it possible that the scribe left his work unfinished, because he signs off with a rather attractive fleuron and the auspicious śrịh (see Figure 1). These two elements suggest that he thought of his job as finished.

The text is composed in a mixture of verse $(660+)$ and prose passages, and is interspersed with over 150 quotations in, again, both verse and prose (typeset in italics in the sample chapter here, below). With the exception of ch. 1, most of the content is what a preacher should be addressing to his audience directly, but there are some prose passages, typically at the beginning and end of chapters and sections, which are a kind of meta-text, containing instructions for the homiletician (typeset in boldface in the sample chapter).

As for versification, while our author is on the whole an elegant and at times even brilliant writer, he is not an outstanding poet. However, he does handle a wide variety of metres correctly and with relative ease. The preference for shorter verses (i.e., under fourteen syllables per line) is abundantly clear. Given the rhetorical nature of the work, this is very likely not accidental. It stands to reason that a preacher should have been aiming at easy intelligibility, wishing for his point to make an immediate impact, rather than to occupy the audience's attention span with making out an intricate verse. Even when the stanzas are longer (e.g. sragdharā), they regularly consist of several syntactic units, making them easy to follow. The author is most comfortable in lines of the upajāti, here in the sense of a discretionary mix of indravajrā and upendravajrā quarter-verses, as well as the latter two patterns themselves, where indravajrā stanzas are far more numerous (in a ratio of 7 to 1 ). The total of such upajāti verses is over 250 , close to $40 \%$ of the entire prosodical body, but if we add

12 The passage in question says (Ms 22v3): tac chāstuh pratipüjanād iti pürvavad vācyam | "[Then,] one should recite as before [the passage] beginning with 'Therefore, by worshipping the Teacher." No such passage can be found in the text before this point. 
the purely indravajrā and upendravajrā verses, we come close to almost half of the versified text. The vamśasthavila, which is essentially an extension of the indravajrā, is also common (ca. 6o stanzas). The humble anuștubh is also used fairly frequently (ca. 10o stanzas); the number of vipula varieties is noticeable, as these amount to about one fifth of the total. These are perfectly regular, with only very few instances where the position of the caesura (yati) is somewhat debatable. The vasantatilakā is also very common; such verses make up almost one sixth of the total. For a complete list of metres employed in the chapter studied here, see Appendix $1 .^{13}$

The work is rich in quotations $\left(15^{\circ}+\right)$, in both prose and verse, and from both Buddhist lore and outside of it. However, referenced quotations are rare. The thus all the more notable exceptions are the Śrämanyaphalasūtra (Ms 24v2), the Cürnakarmavibhanga (Ms 34v5), and what look like parts of a tripartite canon, but these instances too are rare: sūtra (Ms 8r1, 32v2, 44v1), abhidharma (Ms 33v2), vinaya (Ms 42v5). ${ }^{14}$ The quotations function in the same way as the textus in Christian homiletics, although our author rarely starts a discussion stemming from them, rather using scripture to illustrate, substantiate, or confirm a point. However, some of the openings implicitly contain an agama passage: a good example of this is the opening of the third disposition of ch. 3 (Ms 11v3-12r1), where the prose passage is clearly based on an equivalent of the Pāli Mangalasutta, the first verse of which is then immediately quoted. These textus passages are as a rule extremely short, sometimes consisting of a single word. This clearly indicates that the author expected a great amount of learning and mnemonic capacity from the preacher. It can be observed that scriptural quotations occur in greater numbers where the presumed audience is Buddhist and their occurrence is kept to a minimum where it is not. For example, the number of textus passages in ch. 2 is kept to a minimum and even those cited have uncontroversial content. Other chapters $(12,13,14,15)$ use no textus whatsoever. The language of the scriptural quotations poses a most serious problem. Many passages are clearly not Sanskrit, but some kind of Middle Indic. However, there seems to be a possible tendency in the transmission to Sanskritise

13 For what may be gathered from such a statistical analysis of metres, see Hahn 1983a. Ch. 11 is, from a metrical viewpoint, somewhat unusual: as many as six metrical patterns out of the sixteen employed here are used only in this chapter and nowhere else in the text. I am not sure about the implications of this observation. Could it mean that we are dealing with a different author or a co-author? Are these verses silent quotations from a writer with a penchant for rarer metrical patterns?

14 I use the word 'canon' with the understanding that typologically speaking, the authoritative body of scripture that the author cites reveals a 'practical', not a 'formal' canon. For this distinction, see Blackburn 1999, Silk 2015: 13-15. 
these passages, and thus we cannot be certain what the author's originals may have looked like. Given the linguistic register of most canonical passages, it is clear that some amount of diglossia or even polyglossia was natural for both the preacher and the audience. However, ch. 10, which deals with addressing accusations of inappropriate linguistic usage extensively, might suggest that receptiveness to these passages and non-standard Buddhist idioms was not always a given in Brahmanical society.

Silent quotations of non-scriptural sources are probably quite numerous, but of these I could trace only a handful. For example, a key verse on the superiority of the Buddha (st. 2.5, Ms 2r4) is an incorporation of st. 10 of the *Devātiśayastotra or Devatāvimarśastuti of Śaṃkarasvāmin or Varāhasvāmin, further testimony to the popularity and early date of this work. ${ }^{15}$ The author freely borrows verses and prose passages from Âryaśüra's Jātakamāla (ca. 4th century), but he never references the name of the author or the overall title of the work, only the titles of individual chapters. ${ }^{16}$ Our author also quotes, again without any referencing, other works attributed by tradition to Âryaśüra. ${ }^{17}$ This

15 For the latest edition, see Schneider 2014. A new manuscript has been found recently which attributes the work to one Varāhasvāmin. I thank Prof. Schneider for this information (e-mail, May 2019).

16 Referenced jātakas of this collection are nos. 1 (Vyāghrī), 2 (Śibi), 3 (Kulmāṣapiṇụī), 4 (Śreșṭhi), 5 (Avișahyaśreșthi), 6 (Śaśa), 8 (Maitrībala), 11 (Śakra), 12 (Brāhmaṇa), 13 (Śibi with Unmādayantī), 14 (Supāraga), 15 (Matsya), 16 (Vartakāpotaka), 17 (Kumbha), 20 (Śreșṭhi), 23 (Mahābodhi), 24/27 (Mahākapi), 25 (Śarabha), 26 (Ruru), 30 (Hasti), 32 (Ayogṛha), and 33 (Mahișa). Our author was familiar with other jātaka collections too, since some of his references cannot be traced in Āryaśūra.

That textus passages, their explanations, and jātaka recitations were combined in sermons is also shown by Haribhațta in an illuminating passage in his prologue (Jātaka$m \bar{a}\left(\bar{a}^{H}\right.$, p. 42$)$ :

dhārmakathiko hy ārșasūtram anuvarṇya paścād bodhisattvajātakānuvarṇanayā citrabhavanam iva pradīpaprabhayā sutarām uddyotayati śrotrjanasya ca manasy adhikām prītim utpādayatīti bhagavatas traidhātukopapannānām sattvānāṃ vyasanaparamparāpanodāya samutpāditamahāpraṇidheś caritam anuvarṇyamānam apāstastyānamiddhadoșair avahitamanobhị̣ śrotrrbhir amṛtam iva pipāsubhir anekasaṃsāraduḥkhakșayāya samāsvādayitavyam iti $\|$

Tr. by Khoroche (2017: 10):

"A preacher first expounds a saying of the Buddha then, as if lighting up a picture gallery with a lamp, illuminates it further by recounting a jätaka of the Bodhisattva, and thereby fills the minds of his audience with enormous joy. With this in view, the audience should shake off sloth and torpor, pay attention and, as though with a thirst for nectar, relish the recital of a deed of the Lord Buddha, who made the momentous vow to banish the unending ills suffered by beings born in the three states of existence, so that the misery of countless rebirths should cease." 
is intriguing, because modern scholars generally do not accept that the following three works are by the author of the Jätakamālā. ${ }^{18}$

i) Our st. 3.57 (Ms 14r2, mentioned on Ms 51 vi as well; see n. 72) is st. 22 of the *Subhāṣitaratnakarandakakathā; our author provides a lengthy elaboration on this verse, which changes the way we have edited and understood it so far.

ii) Again without any referencing, there are a number of incorporations (not always verbatim) from the Pāramitāsamāsa as well. ${ }^{19}$ E.g. our st. 3.116 (Ms 19v5-2orı; with some variants) = Pāramitāsamāsa 6.23; stt. 5.34-35 (Ms $24 \mathrm{~V} 2-3)=2.63-64$.

iii) Finally, stt. 5.48-50 (Ms 25v1-3) are from the *Supathadeśanāparikathā, the original Sanskrit of which is lost, but judging by the Tibetan translation (Derge no. 4175, 5v7-6r2) it is certain that it contained these verses.

Besides these directly traceable passages, the work is imbued with Āryaśüra's diction and imagery, so much so that one might suspect that the author was, at least in a spiritual sense, a disciple of the famous poet. Thus it is all the more curious that the name of the master is never mentioned. An author explicitly referred to is Kumāralāta (Ms 12r5, 43v2), an early (ca. 3rd century) and very popular author of a collection of parables (drștānta) called the Kalpanāmaṇ̃̂titika Drșțāntapañktih. ${ }^{20}$

Outside the Buddhist world, the author is quite familiar with Sāmkhya, Vaiśeșika, Digambara Jainas, and a school of thought he calls that of the Nirgranthas, very likely the group we usually refer to as the Ājīvikas. The teachers of these schools are referred to as Kapila, Ulūka, Maskari, Pūraṇa, and Vardhamāna (Ms 2r3, 3v3, 8r4). There are references to the grammatical tradition of Pāṇini (Ms 47r4), to the grammarians Bhāguri and Śonaka (Ms 48vi), ${ }^{21}$ to dha-

18 Cf. however the objection voiced in Mirashi 1961 regarding the *Subhạsitaratnakarandakakatha , which in light of this text might gain new strength. See also Yamasaki 2018, who attempts to study the problem from a stylistic point of view. I am not of course suggesting that the work per se is by Âryaśüra after all, rather that it contains more verses of this author than was previously thought.

19 For the latest edition, see Saito 2005.

20 See Horiuchi 2019. The titles of parables I could identify are no. 22 (Panadvaya), 34 (Āśìvișa), and 57 (Vyāghrabhīṣitaka). The chapter numbers are according to Huber 1908 (where, in spite of its title, the underlying Chinese text, Taishō no. 201, is a translation of this work and not Aśvaghoṣa's Sūtrālaṃkāra). For a partial Tibetan translation, see Hahn 1982. It is possible that our author was familiar with other collections of parables; see for example the untraced 'Parable of the Door and the Wall' cited at the end of the first disposition in ch. 11.

21 These two appear in a verse listing some grammatically sanctioned alternatives, thusat least for our author-proving that Sanskrit morphology is not absolute. The identity of 
rmaśāastras (Ms 37v1-1, 54v5-55r1 is an unreferenced quotation of Manusmrti 10.92), to an arthaśāstra which is not that of Kauțilya (Ms 34vi), ${ }^{22}$ and to Pāśupata Śaivas. ${ }^{23} \mathrm{He}$ is also familiar with a variety of Purānic stories, almost all of which can be traced in the Epics, with the notable exception of the lingodbha$v a$ myth. ${ }^{24}$ There are no explicit mentions of Mīmāṃsā, Nyāya, or later Śaiva schools.

Judging by the environment sketched above, the most plausible time bracket we can place our author into is the $5^{\text {th }}$ century CE at the latest. Unfortunately, there are no traces whatsoever which would allow us to localise him on the Indian Subcontinent (which is probably consistent with the author's wishes).

The deferential tone of the preacher (see e.g. n. 29) suggests that the author was working in an environment where Buddhists were in a minority: not unknown, but lacking political power. St. 30 and its environs below is a case in point: Brahmanical attitudes to mourning are both approved (tacitly) and criticised (subtly). It is particularly noteworthy that the 'caste-system' is nowhere attacked. When it comes to offering advice on personal devotion, a carefully crafted passage (Ms 2v2-4) states that a wise man should examine the virtues (guna) of his object of piety (bhakti), rather than following the king's restrictions (rājanigraha), family tradition (kulakrama), or because of suspecting some kind of danger (bhayāśank ā), or because of being attached to some kind of miserly hope (āśākārpanya). Even with regard to criticism of rival gods, we see a variety of approaches. While ch. 7 is replete with scathing attacks on their various exploits as narrated in Purānic stories, in other sections (e.g. Ms 8v2) the

the second author remains unclear; a possible alternative is Śaunaka, the putative author of the Rgvedaprātiśākhya.

22 The passage in question claims that among addictive vices (vyasana) stemming from pleasure-normally hunting, dice, women, and drink—drink is the worst (ryasaneșu pānam adhikam), whereas Kautilya argues that the worst of all is dice; cf. Olivelle 2013: 336-339.

23 The Pāśupatas are not named so, but their teaching is referred to in a mocking verse (st. 7.14, Ms 37r2-3) as śāstraṃ pañcārtham.

24 See Kafle 2013. If I am correct in positing the age of the text, this might be one of the very earliest circumstantially datable references to this famous myth meant to show Siva's superiority over Brahmā and Viṣnu: the central element is that he displays his infinite linga while the other two gods vie with each other in vain to find either of the two ends. Our author concludes (st. 7.8, Ms 36v5):

rudrasya śaktipravidarśanārtham sa ced vidhị kiṃ na bhuje krto 'sau |

yuktạ̣ (em., yuktah Ms) sapam darśayitum harasya tayor dvayoś cāpy ubhato 'nusartum $\|$

"If this is a way to demonstrate the power of Rudra, then why was it not done with regard to his arm? How can it be proper for Hara to display his penis and for the other two to proceed on either side?" 
preacher simply refuses to talk about these issues 'in order to maintain civility'. Moreover, some passages suggest that the preacher was not actively seeking out an audience by missionary zeal but rather created such conditions where the audience came to him. ${ }^{25}$ Unfortunately, these conditions, such as some kind of proclamation or advertisement, are nowhere specified. ${ }^{26}$

25 E.g. after a masterful exordium praising the virtues of the audience, the preacher is supposed to say (Ms 2r1-2):

tad evaṃgunāạm śreyo'rtham abhigatāṃ parșadam ko nāma dharmātitheyena na pratipüjayet |

"Well then, what kind of person would not repay the honour to an audience of such virtues, which has gathered here desiring the summum bonum, by the hospitality of the Law?"

Readers unfamiliar with rhetorical terminology might find the following definition of exordium useful (Holmes 1755: 16; I retain the original formatting): "The Exordium, or Beginning of an Oration, is that in which we are to give our Audience some Intimation of our Subject, and from the Nature of it to prepare their Minds to Benevolence and Attention. In which Part the Speaker ought to be clear, modest, and not too prolix."

26 We can perhaps extrapolate the circumstances from sources such as the Ratnarāsisisutra (section IV.6 in Silk's numeration, for the reference see below). This passage is (in part) quoted thus in the Sikșāsamuccaya (Cambridge Ms Add.1478, 33r3-4; Bendall 19o2: 56, who does not seem to mention the gloss):

ye dhārmakathikā bhikșavo bhavișanti, teșām pratīhāradharmatā kartavyā yāvad dhārmaśravaṇikāś codyojayitavyāḥ, parșanmaṇdalam parisaṃsthāpayitavyaḥ, sāṃkathyamaṇdalam (gloss: anyonyakathānivāraṇāt) viśodhayitaryam yāvan sādhukārabahulena cāsya bhavitaryam.

The tr. in Bendall and Rouse (1922: $5^{6-57)}$ is somewhat puzzling:

"For the monks who are preachers he [scil. 'the serving monk'] must do duty as doorkeeper; and until the congregation has to be dismissed, the assembly-room must be kept in order. In a connected discourse the room must be kept clear until there is the abundant applause which is his due."

Amongst other mistakes, the translators did not consult the text cited and took the yāvats (which I have de-italicised above) as part of the main text and not as meta-text denoting elided passages. For the entire passage of the sütra, see Silk 1994: I.328-329 for the translation, II.441-442 for the Tibetan text (both currently being revised, I shall therefore not discuss the philological problems here):

"Now, Kāśyapa, the superintending monk shall not assign tasks to those who are reciters of the Teaching. He shall cause them to enter villages, towns, markets, districts and royal metropolises and preach the Teaching. He shall inspire the audience. He shall purify an assembly area. He shall arrange an assembly area for the elegant preaching of the Teaching. The superintending monk shall expel those monks who do injury to a monk who is a preacher of the Teaching. The superintending monk shall always greet the monk who is a preacher of the Teaching, and shall congratulate him generously."

Thus, the administrative duties, such as arranging for an invitation, preparing the venue, gathering the audience, keeping them in check, and occasionally animating the proceed- 
As to the school to which the author may have belonged, this question will require further study. There are some signs that indicate a Sāmmitìya/Sammatiya background, ${ }^{27}$ but my current hypothesis is that the author was not only doing his best to ignore internal sectarian divides (provided that such barriers were meaningful to him to begin with), ${ }^{28}$ but also attempted to provide a united front of 'universal Buddhism' to those who were potential converts or new to the religion.

What is perhaps the most important feature of the text is that its sermons are addressed almost exclusively to laypeople, both Brahmanical and Buddhist. The preaching seems to be almost exclusively communal. I cannot find any trace that any of the sermons were meant for a private audience, with the sole exception of the chapter edited here, the occasion of which is dictated by circumstance, namely the death of a friend, relative, or retainer. The plural is also used for the Buddhist community (e.g. vayam, naḥ, 1st person plural

ings was relegated to the superintending/steward/manciple monk (vaiyāprtyakara). It is reasonable to assume that this was the case for our author too.

27 Some circumstantial evidence for this is as follows:

1) The unreferenced quotations from the Dharmapada linguistically stand closest to the Patna/Saindhava version (several instances, including some in the chapter edited here). For the hypothesis that this was the Dharmapada of the Sāmmitīyas/Saṃmatīyas, see Dimitrov 2020.

2) Some of the scribal/phonological/morphological features suggesting a Saindhavī background (cf. Dimitrov 2020: 117-146, 183-184) are:

a) consonant clusters with -r-: $k r, g r, t r, p r, b r$, etc. (however, there are no signs of -ttrand $-g g r-)$;

b) the use of all three sibilants $(s, s, s)$ and their geminates: e.g. aśśamedho (Ms $\left.{ }_{15} \mathrm{r}_{5}\right)$, vaśśaśataṃ (Ms 15v1), sappuruṣā (Ms 24r5), upoṣadhassa (Ms 25r2), puruṣassa (Ms 33r1);

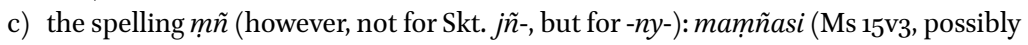
24V2, 31r1);

d) the gerund $\tilde{n} \bar{a} t t \bar{a}$ (Ms 29v3);

e) the nominative singular bhikkhū (Ms 21v1, 21v1-2).

3) The fact that the future buddha is called Ajita and not Maitreya (st. 3.111, Ms 19v1); cf. Karashima 2018.

4) Mention of a buddha of yore by the name Mahāsāāyamuni (Ms 36rı-2), perhaps as a way of saying 'the previous Śākyamuni'; cf. Skilling 2006: 104-106.

28 This includes what some people might anachronistically call the Hīnayāna/Mahāyāna divide, too. The author mentions donors who might be 'holders of the bodhisattva vow' (bodhisattvapratijñā) at least thrice. Ms 10r4-5: bodhisattvapratijñe tu dāyake sarvajñatām prāpnuhitiyojyam|"In the case of a donor who is a holder of the bodhisattva vow, one should add [to the benediction]: 'May your obtain omniscience!"; 11v2: bodhisattvapratijñe tu dātari sarvajñatām prāpnuhītiyojyam |(ditto); 17r4: bodhisattvapratijño dānapatir evam sampraharșayitavyah | "A sponsor who is a holder of the bodhisattva vow should be gladdened as follows." 
verbs), probably meant thus and not as a plural of humility. The common linguistic code of Sanskrit suggests a learned Brahmanical audience. Indeed, the preacher seems to find common ground with the audience by calling them Āryas in opposition to the non-Āryas or barbarians (mleccha). The terms do not seem to suggest anything racial, as the preacher points out that the crucial distinguishing definition between the two groups is that Āryas follow the Dharma, or perhaps better said "a dharma". Social standing is very rarely referred to, but one passage suggests that the audience could be headed by some local potentate or even a king. ${ }^{29}$ While the primary targets for securing sponsorship were obviously well-to-do laypeople, the author also includes shorter sections specifically dedicated to donors of humble means (ch. 3, fourth disposition and explicitly in the seventh). That the audience consisted of both Buddhists and non-Buddhists is very clear. It is somewhat less clear what kind of Buddhists the author had in mind. As already mentioned (n. 28), he seems to distinguish a group who holds 'the bodhisattva vow', i.e. very likely followers of the Mahāyanna, and he does so without any trace of animosity. On the whole, the text does not deal with internal doctrinal discussions, again suggesting that the author favoured a catholic approach when it came to his co-religionists. There does not seem to be any effort on the preacher's part to convert the laity to monkhood. As for the non-Buddhist audience, it is noteworthy that the author assumes a modicum of learning on their part, because he addresses them in a way that presupposes a basic familiarity with the Buddha's person, his vita/s, and his moral teachings. Especially ch. 2 can be said to be a kind of halieutic theology in practice or missionary preaching. It is perhaps here that the preacher must have found it most difficult to find common ground. This our author resolves for the most part with an appeal for the love of virtues (guna), most importantly civility and reason, and an earnest wish for the summum

29 Ms 48v2-3:

yadi kaścid avirādhanakșamạ̣ parșatpradhāna issvaro rājā vā svaśaktikhyātikāmo brūyād ayam apaśabda iti tasmin pūrvam eva vācyam | anaparādhavijayaśrīr atrabhavatah | kaścin nāma parșadi tvadvidhena vidușā saha vivadan vidvān ity ucyata iti nirvivādā vayam bhavatā

"Should the chief [guest] of the assembly, a potentate, or a king - somebody who should not be offended-out of a desire to display his own power say 'This [statement of yours] is a [linguistic] barbarism!', he should be answered from the very outset [as follows]: 'Thy Fortune of victory is without blemish! Who in this assembly could possibly called a scholar, should they enter into a debate with a learned man such as yourself? Thus we are unable to enter into a debate with you, sire!"

Note the deferential tone of the answer. In other words, the preacher is advised not to speak truth to power but to retreat with flattery. 
bonum. If we wish to draw another parallel with Western homiletics, the most likely kindred scenario would be a converted Christian preaching to his fellow pagan Hellenes.

It is perhaps also worth pointing out that the text does not use the term dharmabhānaka anywhere. Instead it prefers the designation dhärmakathika for the preacher (and even that is used only once, Ms 46r1) and dharmakatha for the sermon (Ms 1v1, 3v1, 46r4, 47v1 with $\left.s a d^{\circ}\right) .{ }^{30}$ The audience is simply called parșat (Ms 1v2 parișat ex em. metri causa, 2r2, 46r4, 48v2 and 48v3).

I hope that the above brief outline will persuade the reader that the anonymous *Saddharmaparikatha is an extremely rich work that merits closer and more extensive scrutiny. What we see here is a unique record of a mature homiletical tradition. Since public preaching with the aim of attracting converts and patronage must have been a widespread exercise, it is somewhat surprising that we do not have more major works of this genre. ${ }^{31}$

In the next part of the paper, I will provide a sample from this extensive work, a chapter dealing with grief (śoka). Grief, a universal human emotion felt at a loved one's demise, is a state of mind in which one is especially prone to turn to religion for solace. Given Buddhism's widespread interest in mortality, impermanence, and the fate of beings after death, it is surprising that there are very few instances in the surviving literature that deal with how to handle grief, either experienced by oneself or by one's flock, on a practical level..$^{32}$ One

30 For a discussion of these two terms, see Drewes 2006: 218-269 and Drewes 2011.

31 The emphasis is on 'major'. There are of course several short works in the Tibetan Canon with ${ }^{\circ}$ parikatha in the title and it can be reasonably assumed that they were used for preaching; see for example Dietz 2000, a study of the *Kaliyugaparikathā attributed to Mātrceța. In light of the present work, I am now more than tempted to consider the *Subhāșitaratnakarandakakathā as a collection of pericope verses, which were elaborated upon according to the occasion (for how such verses were employed, see st. 23 below). The idea that this collection was used by preachers has already been voiced, see Banerjee 1954: 86: "It was composed particularly for the use of monk preachers for inspiring in the minds of the laity a faith [sic] in Buddhism."

32 There are some short passages in dharmaśāstra literature and purānas that supply examples of how such post-mortem sermons may have sounded in the Brahmanical world; see Kane 1953: 236-237. In Kane's examples, both the Yãjñavalkyasmṛti and the Viṣnudharmottara suggest that the sermon was not delivered by a religious specialist but by elders or wise men of the family. Yājñavalkya's agent is not clear, but the Mitākșarā commentary says that they are the kulavṛddhāh; for the latter, see 2.78.1ab: budhair āśvasanīyās ca bāndhavair mrtabāndhavāh | "The relatives of the deceased are to be comforted by wise kinsmen." For a kārya example, see Raghuvaṃśa 8.83-9o, an epistle-style message sent by Vasiștha to king Aja upon the loss of his beloved queen. For elegantly expressed Jaina views with many conceptual parallels with our text, see e.g. ch. 29 of the Subhassitaratnasamdoha (pp. 85-87, stt. 712-739) of the Digambara Amigati (ca. 1oth century). 
such rare example is a work attributed to Aśvaghoșa, the Śokavinodana. Until very recently, this work was thought lost in the original and was known only via its canonical Tibetan translation (Derge 4177/4505, Peking 5418/5677), but the entire text can be extracted from the aforementioned Tridandamāla and a Chinese rendering too has been identified. ${ }^{33}$ This soliloquy is similar in tone to the chapter I deal with in the present paper.

The guiding argument of our author is that grief is an undignified emotion inasmuch as it is rooted in attachment. Nursing it (anu $\sqrt{v} r t)$ is not only pointless, but dangerous, because it leads to depression, which in turn causes one to neglect worldly and religious duties. Moreover, it has a detrimental effect on loved ones. Instead, one should display steadfastness and view the unfortunate event as something that prompts insight into the inevitable transience of beings and therefore serves to confirm the validity of the Buddhist message. This, essentially, is the thought process behind the author's inventio displayed in all three sub-chapters or dispositions.

Of the three dispositions offered here (numerated in the translation as I, II, and III), the first is less clearly Buddhist in tone, and, minus some cosmographical elements, doctrinal concepts are brought forth only at the very end. Terms such as religious duty (dharma) and scriptural learning (śruta) are used somewhat ambiguously; they can be interpreted in a Buddhist or non-Buddhist framework alike. Moreover, only one textus and a single parable are cited. The third is much more emphatic about its sectarian identity and was probably the option reserved for an already converted audience. This is also indicated by the high number of scriptural passages, no less than thirteen. Here, the practice to overcome grief is a recollection (anusmrti) of the Buddha himself, who is also presented as a template for the preacher's efforts to gently steer the pious away from bereavement. The second disposition is somewhere in-between the two in how "Buddhist" it is. Here we find two textus passages and one jātaka; however, there is a reference to meditating on the Four Truths, some technical terms are employed (e.g. punyakriyāvastu and nirvāna), and some words are part of the Buddhist sociolect (e.g. samucchraya for body). This disposition distinguishes itself by its style: the author starts out with a pericope verse, essentially a list of disadvantages connected to grief, and then develops it. This is a favoured rhetorical approach seen elsewhere too in the *Saddharmaparikatha e.g. the fifth disposition of ch. 3 , the first, second, and third dispositions of ch. 5 , and elsewhere. What is more, here the author skilfully blends in two further

33 See the forthcoming article "The Benefit of Cooperation: Recovering the Śokavinodana ascribed to Aśvaghoșa" by Jens-Uwe Hartmann, Kazunobu Matsuda, and Péter-Dániel Szántó. 
pericope verses (one from ch. 3 , one from ch. 5 ) into the main discourse; these, doubtless depending on the circumstances, may or may not have been elaborated upon.

As for poetic style, some passages may be singled out as better crafted than others. The barrage of prose sentences after st. 4 is somewhat reminiscent of Bāna and probably had a convincing effect. The long dandaka st. $3^{1}$ starts out very promisingly and with a touching image, but ends abstrusely. Some verses are elegant enough to be included in aphoristic collections, e.g. stt. 33, 36, 38, or-perhaps one of the best- 45 , but this is evidently a matter of taste. Yet others are obscure (but this, at least in part, could be due to faults in transmission) or slightly clumsy (e.g. unwarranted punaruktis such as in stt. $35 \mathrm{~cd}, 5_{1} \mathrm{bc}$, or $53 \mathrm{ac})$. The diction is on the whole sober and unadorned; there are only a handful of similes $(2,26,35 \mathrm{~b}$, etc.) and metaphors or metaphorical expressions ( $9 \mathrm{a}, 25 \mathrm{~b}, 4 \mathrm{Od}$, etc.). Given the strongly performative nature of the text, the abundance of rhetorical questions is perfectly understandable (e.g. 3, 4cd, 7cd, 17, 23, etc.). Next to Āryaśūra's pervasive influence, some echoes in the present chapter might suggest that our author was quite familiar with the Buddhacarita and the Raghuvamiśa.

In spite of my best efforts and the very generous advice I have received from colleagues, especially Harunaga Isaacson, some sentences remain obscure, most significantly two rather frustrating cruxed passages (st. 5 b, where the blurred image is difficult to make out, and the prose after st. 24).

\section{$2 \quad$ Edition and Translation of ch. 11}

The following abbreviations are employed in the apparatus:

st. standardisation

corr. correction

em. emendation

conj. conjecture

diag. conj. diagnostic conjecture

Mspc manuscript's reading after correction (scribal or a lector's)

$\mathrm{Ms}^{\mathrm{ac}} \quad$ manuscript's reading before correction.

$\dagger \ldots \dagger$ readings bracketed by cruces of desperation are beyond my understanding

The formatting, verse numeration, and punctuation are entirely mine and divergences from the scribe's usage of dandas (and resulting sandhi) have not been noted separately. Banal scribal or lector's/lectors' corrections have not been noted. Homorganic nasals, sibilants, $m$-virāma type anusvāras, $s$ for visa- 
$r g a$, geminations under repha, degemination of $t v a$, and non-metrical $c c h$ have been silently standardised. Avagrahas were added where appropriate. Quotations are italicised. The author's instructions to the preachers are typeset in bold. In the case of Pali, all references are to the Pali Text Society editions with the standard abbreviations (thus Thī = Therīgātha, $\mathrm{Sn}=$ Suttanipāta, etc.; $\mathrm{cf}$. https://cpd.uni-koeln.de/intro/vol__epileg_abbrev_texts).

\section{śokavinodanārtham evaṃ parikathā vācyā |}

In order to alleviate grief, a sermon should be delivered as follows:

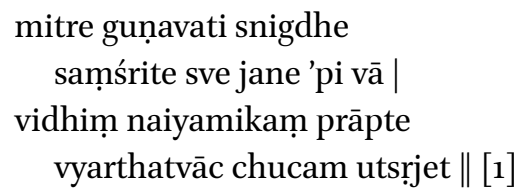

(I) When a virtuous, beloved friend, or a retainer, or even a family member has reached the certain end, one should give up grief, for it serves no purpose. [1]

avītarāgasya satạ

kāmaṃ śokaḥ priyātyaye |

mahān ogha ivābhyeti

taṃ tu nānubhramed budhah $\|[2]$

Granted, for one who is not yet free of attachment, grief comes, overwhelming like a mighty flood, at the demise of a loved one. But a wise man should not follow him in this error. [2]

kā hi tena guṇāvāptis

tasya kaivātmano bhavet |

samānasukhaduḥkhānāṃ

suhṛdāṃ svajanasya vā $\|$ [3]

For what possible gain can be acquired by that [grief], either for the departed [loved one], or for oneself, ${ }^{34}$ or for one's friends who share [both one's] pleasure and pain, or for one's kinfolk? ${ }^{35}$ [3]

34 Cf. Viṣnudharmottara 2.78.17cd: nopakuryān naraḥ śocan pretasyātmana eva ca \| "A grieving man will be of no help either to the departed one or to himself."

35 Cf. 31d, 51cd below. 
na śucam iti bhajeta paṇditas

tadupaśame tu yateta vīkṣayā |

ka iva hi guṇapakṣaghātinam

sukhavikalātmakam artham āśrayet || [4]

Thus, a learned man should not nurse grief, but should strive to calm it with insight: for who could possibly adhere to something which not only inflicts casualty on the side of virtue but also never provides any comfort? [4]

kathaṃ punar ayaṃ guṇapakṣaghātī śoka ity ucyate | naitad vyākhyānagamyam pratyakșavispașțatvāt | śokatamisrām anuvartamānasya hi janasya sạ̣hriyate dhairyaśobhā | nimīlyate buddhisāmarthyam | āchidyate smṛtiparākramaḥ | śāntim eti tejạ̣ | tyajaty enam ojasvitā | nainam upaiti pramo ${ }_{[49 v]}$ daḥ | dūrībhavaty asmān manaḥprasādaḥ | dharmārthakīrtikșameșv api kāryeșu visrasyata evāsyotsāhaḥ | antardadhāti śuklatvam | manaḥsaṃkṣobhād yathākālam āhārādyapratipatteś calatām upaity ārogyam | sopaplavaiva bhavati kāntiḥ | pramlāyate dvișattamaḥpramāthinī dīptir vilīyate ${ }^{36}$ ca balam | ākulībhavati śrịh | śithilībhavati dākșinyavinayādaraḥ | kārśyam upaiti paṭutā| astam upaiti saumanasyam durādhāraṃ ca bhavati sukham | ity evaṃ guṇapakṣaghātī janasya śokaḥ |

But how can one say that grief inflicts casualty on the side of virtue? This does not [even] need any explanation; it is plainly clear to see. For a man who dwells on the gloom of grief loses the distinction of being steadfast; the capability of his intelligence withers; his power of being mindful is split asunder; his charisma fades; his energy leaves him; calm joy approaches him no more; his good mental disposition avoids him; his enthusiasm for any kind of business allowing for [the fulfilment of] religious duty, making money, or seeking fame is lost for good; his complexion darkens; because of [this] mental disturbance, he does not eat and so on at the proper time, and thus his good health becomes unstable; his charm is greatly affected; his valiance for quashing the enemy that is darkness shrivels and his strength fades; his Fortune is disturbed; his care for civility and modesty becomes lax; his skills become reduced; his cheerfulness wanes and he finds it difficult to achieve comfort. So, it is thus that a man's grief inflicts casualty on the side of virtue.

36 vilìyate] em., valīyate Ms. 
tad evaṃ guṇapakṣoparodhinaṃ śokaṃ guṇavatsalātmanaḥ sarvakālaṃ tadanurakṣaṇodyatamater nālam anuvartitum āyuṣmatah |

Hence a gentleman, one who loves virtue, should never dwell on grief, an impediment for the side of virtue as explained above, [precisely] because he is constantly intent on cultivating virtue.

tat sādhu tām eva bhajasva saṃjñāṃ

†ko py eșu rūạhā tarayāntameșu†|

guṇoparodhī na hi śokaśatrur

bhavadvidhair evam upekșaṇīyah \|| [5]

Hence you should do well to resort only to that notion $\uparrow \ldots \dagger^{37}$ Verily, the foe that is grief, an impediment of virtue, should not be disregarded in this way by good people such as yourself. [5]

saṃvardhanālabdhaphaleșu kāmaṃ

svabhāvabhūteșu satāṃ guneșu |

śokaḥ kim evāpatito 'pi kuryād

guṇavyalīkaṃ tu na marṣaṇīyam $\|$ [6]

Indeed, though grief may strike, what can it do to virtues, the very essence of good men, the fruits of which have been obtained by careful cultivation? But one should not put up with the opponent of virtue [either]. [6]

anyatra tāvat pravijụmbhamāṇam

necchanti śokạ̣ guṇapakșaśatrum |

manotibhūmim tam avajñayaiva

prāptaṃ tu vidvān iha kaḥ saheta $\|[7]$

Now, [people] are averse to grief, the foe of the side of virtue, when it is manifesting in others. So when [grief] starts to overwhelm the mind with contempt, how could a wise man put up with it in this world? ${ }^{38}$ [7]

37 The reading of this $p \bar{a} d a$ is highly uncertain as the photograph is out of focus on this side of the folio.

38 The translation is tentative. 
dharmārthayuktaṃ bahu cintyam asti

kṛtyam ca te kīrtisukhopapādi |

manas tad eva pratipādayasva

bhavadvidhānām ayaśo hi śokaḥ || [8]

There is plenty for you to be preoccupied with—religious duty, making money - and plenty of business for you to see to-[deeds] that bring fame and comfort [respectively]. Direct your mind to those alone! For grief is disgraceful for good men like yourself. [8]

alpasattvapratipannā khalajanarathyā hy eșā |

Verily, this is the way of base men, resorted to by those of little courage.

avicārya toyagatacandracalāṃ

jagatah sthitim dhṛtigunais tanubhị̣ |

dayitātyayeșv atha bhavanti janāḥ

pṛthuśokadainyavihṛtadyutayah \| [9]

Because their virtue of steadfastness is weak, men do not reflect on the fact that the state of the world is transient like the Moon reflected in water; and so, when those dear to them pass away, their lustre is snatched away by the depression resulting from intense grief. [9]

gāmbhīryagūḍhāpi tu sajjanasya

prakāśatām eti tadā gunaśrīḥ |

yathaivam āpat katham abhyupaiti

na caiva śokah katham abhyupaiti || [10]

On the other hand, it is precisely then that the splendour of virtue in good men comes to light, even if it was previously well hidden because of their composure. This being so, it may so happen that disaster befalls them, but grief will never prevail. ${ }^{39}[10]$

alabdhāvakāśāni śokena dhairyātmakatvāt

kṛtajñasvabhāvāt tu cittānugavyāhṛtāni ${ }^{40}$ |

39 I understand both occurrences of katham in the sense of katham api.

40 cittānugavyāhṛtāni] diag. conj. (Szántó and Isaacson), cintānugunaavyāpṛtāni Ms. 
parityaktabhūṣāṇi ${ }^{41}$ lokānuvṛttyā budhānāṃ mukhāni priyavyāpadi sve guṇā bhūṣayante $\|\left[1^{42}\right]$

At the time of a loved one's demise, the visages of the wise are unaffected by grief on account of [their] steadfastness, but do utter considerate words because of [their] having a nature of gratitude [towards the departed and his kin] and are unadorned because of [their] compliance with worldly convention; [instead] their own virtues adorn them. [11]

sveșu ca prāṇeṣv api dayām anādṛtya satpuruṣā guṇā ${ }_{[50 r]}$ n evābhipadyante | nānurudhyante doṣapakșam | tad abhibhūyamānam śokadainyenābhyupapattum ${ }^{43}$ arhasi dhairyam | manyuvaśād ivāpayāntī vyavasthāpyatāṃ cetasi smṛtih | āvarjyatāṃ tejasvitā śrutasamāśrayāt | tadanvavekṣaṇāt prabodhyatāṃ buddhih | kutra hi vidyāsthāne kenacic chāstrakāreṇābhyanujñātā śokānuvṛttị̣ | tat prajvālyatāṃ śokatamạ̣pramāthī ${ }^{44}$ lokasthitisvabhāvasaṃdarśakạ̣ prajñāpradīpah |

Moreover, good people do not care even about their own lives, but devote themselves only to virtues. They adhere not to the side of vice. Thus, when [it is] overcome with the depression of grief, you should do well to adhere to steadfastness. Recollect your mindfulness when it is slipping away because of distress! Regain your vigour by listening to the scriptures! Ponder on what you have heard and awaken your intelligence! For what author of treatises in which branch of knowledge assents to dwelling on grief? Light then the lamp of wisdom which dispels the darkness of grief and shows the state of the world as it truly is!

tripișțape 'py asti na śáśvatā sthitị̣

patanti kṛtvāpi mahendratāṃ divah |

parikṣayād dhyānaphalasya cāvaśāḥ

patanty adho brahmagaṇāḥ sahasraśạ || [12]

\footnotetext{
41 obhūṣannị] conj., obhūṣaṇāni Ms.

42 Judging by the punctuation (a danda after mukhāni and a single danda at the end), the scribe did not recognise this string as verse. Neither did I for some time, until I realised that with two interventions, the passage can be made to fit a somewhat rare metrical pattern (simhapuccha). The first conjecture remains diagnostic.

43 ○ābhyupapattum] em., `ābhyupapatyum Ms.

44 'opramāthī] em., ${ }^{\circ}$ pramāthi ${ }^{\circ}$ Ms.
} 
There is no eternal state even in the realms of paradise; [gods] fall from the heavens even though they acted as [their] Great Lords. When the fruit of their meditations is fully exhausted, scores of Brahmās fall powerless by the thousands. [12]

ābhāsvarā bhāsvaramūrtayaś ca

śubhāś ca devāḥ śubhacārurūpāḥ|

adṛștasatyās tata uttare ca

bhrașțadyuto bhraṃśam avāpnuvanti || [13]

The Ābhāsvara gods too of resplendent bodies, the Śubha gods too of pure and beautiful shapes, and those above them who have not realised the truth—with their splendour gone, they reach decay. [13]

bahukalpasahasrajivino

yad arūpāś ca bhavāgragāḥ surāḥ|

svakṛtasya śubhasya saṃkṣayāt

kṣayam āyānty aśivā bhavās tatah $\|$ [14]

And the Formless gods too at the pinnacle of existence, with their lifespan of many thousands of aeons, when the good karma they have accumulated becomes exhausted, they perish and inauspicious births follow. [14]

iti daivatāny api sukhaṃ vividham

svakṛtāśrayāt samanubhūya ciram |

vivaśāni yad vinipatanti divạ

śaraṇatvam asti na bhaveșu tatah $\|$ [15]

In this way even the gods, after having enjoyed for a long time various pleasures on account of their good karma, fall from the heavens powerless. Therefore no realm is a refuge [from death]. [15]

svarge 'py evaṃ janma duhkhhānubandham

vyādhyāyāsakleśakașțạ̣ nareșu |

duḥkhaṃ śuddhaṃ yat tv apāyeșu tasmāj

jātiṃ vidyāt sarvaduhḳhapratișțhām \| [16]

Thus, even heavenly rebirth is tainted by sorrow. As for humans-sickness, toil, affliction, misery. As for the lower rebirths — nothing but suffering. Therefore, one should know that birth is the root of all suffering. [16] 
na cāsti sā nāsti ca duḥkhasaṃbhavah

kuto hi citte 'sati caitaso vidhih |

gataś ca dehah praśamaṃ rujākaras

tadāśrayaṃ syāt kuta eva cāsukham || [17]

If there is no [birth], there is no suffering. How indeed can there be the activity of mental factors, if there is no mind? When the body, the cause of pain, has ceased to be, how can there be suffering, which is rooted in it? [17]

punarbhavam prārthayate tu yāvan

manas tadāsvādavikalpamūụham |

duḥkhasya tāvad bhavati pravṛttiś

chinnā ca tṛ̣ṇā vigataṃ ca duḥkham || [18]

The activity of suffering exists only as long as the mind, deluded by the thought of [life's] relish, desires rebirth. As soon as thirst is put to an end, suffering [too] disappears. [18]

bhavān asārān kṣayiṇas ${ }^{45}$ tu paśyan

duḥkhānubandhāṃś ca nirātmakāṃś ca |

jahāti tṛṣnāṃ ${ }^{46}$ vigamāc ca tasyā

duhkhhasya naivāsti punah pravṛttih $\|$ [19]

But seeing the levels of existence as worthless and transient, both spoilt by suffering and without essence, [a wise man] forsakes thirst [for rebirth]; and when thirst disappears, the activity of suffering returns no more. [19]

tasmād imaṃ śokaparidravāṇāṃ

jātyādiduḥkhasya śamāya caiva |

bhajasva mārgaṃ gatam āryasattvaị

śokānuvṛtter na hi deśakālah $\|$ [20]

Therefore, in order to end the afflictions of grief and to end the suffering beginning with that of birth, you should tread the path traversed by noble beings. For [this] is not the time nor the place ${ }^{47}$ to give in to grief. [20]

45 kṣayiṇas] em., kṣapiṇas Ms.

46 tṛ̣nāạn] em. (Isaacson), tṛ̣̣nā Ms.

47 The irregular deśakālah is poetically sanctioned, cf. Buddhacarita 3.62b. 
evaṃ hy uktaṃ bhagavatā |

$$
e k \bar{a}_{[50 \mathrm{v}]} \text { yano mayā bhikkhave | }
$$

For this is what the Lord taught:

"Oh monks! I [ have taught] the One Way ..."48

avāpya tasmān nṛșu janma durlabham vacaś ca duḥkhakṣayagāmi saugatam |

kuruṣva yatnaṃ svahitāptaye tathā yathedṛ́sam syād asukhaṃ na te punah || [21]

Therefore, having gained a human birth which is so difficult to obtain and the precious word of the Sugata which leads to the end of suffering, exert effort to obtain your own welfare in such a way that you shall experience such suffering no more. [21]

paramadurlabham hi śreyaḥprāptikṣaṇasamavadhānam ity atrātmakāmā na pramādam āpadyante | tadyathānuśrūyata ity atra kavāṭabhittidụsțāntam uktvā vācyam |

Verily, the conjunction whereby the opportune moment for gaining the summum bonum is most difficult to obtain, hence those who desire their own [welfare] do not err with carelessness regarding this. As it is heard - and here, after having narrated the Parable of the Door and the Wall, ${ }^{49}$ one should say:

śreyaḥprāptikṣaṇasyaivaṃ

vīkṣya durlabhatām imām |

śreya eva prapadyasva

tyaja śokam apārthakam $\|[22]$

48 Cf. Mahāsatipațthānasuttanta (DN 22, ii.29o,7-10; also MN 10, i.55,31-56,3): Ekāyano ayam bhikkhave maggo sattānam visuddhiyā soka-pariddavānam (var. ${ }^{\circ}$ paridevānam samatikkamāya dukkha-domanassānam atthagamāya ñāyassa adhigamāya nibbānassa sacchikiriyāya, yadidam cattāro satipațthānā. There is a possibility that the textus is corrupt; perhaps it is to be emended to ekāyano maggo or ekāyano ayam? For a discussion on the meaning of the term ekāyana, see Sujato 2012: 208-218. Also cf. with the end of the third disposition.

49 Untraced. I could not find this title among Kumāralāta's parables. 
Having reflected thus on just how difficult it is to obtain the opportune moment for gaining the summum bonum, strive only for that good and give up harmful (/useless) grief. $^{50}[22]$

\title{
aparah kalpah |
}

(II) [I shall now explain] another disposition:

\author{
kṛ́sodayam duḥkhaphalābhimarśam \\ mahātyayaṃ dharmayaśạ̣sapatnam | \\ necchanti santo'rtham abhiprapattum \\ evamuvidham kas tu bhajed anartham $\|$ [23]
}

Good men do not desire to resort to a benefit that is (i) of paltry gain, (ii) connected with painful results, (iii) of great danger, (iv) an adversary of fame for religious duty. ${ }^{51}$ So what kind of person would entertain such a calamity (i.e., grief) [which is guaranteed to have all of these and more] ${ }^{52}$ [23]

\author{
śokas tu kṛtyapratipattiśatruh \\ kṛśodayo 'smād vigatodayo vā | \\ kālopapannā pațutā kriyāyāḥ \\ kṛtye niyuktā hy udayāvahā syāt || [24]
}

(i) Now, grief is a foe of achieving what needs to be done, therefore it is of paltry or no gain. For [only] timely intensity of action applied to what needs to be done brings benefit. [24]

50 Cf. with the famous stanza of the Bodhicaryāvatāra 1.4 (which, incidentally, on at least one occasion found its way into non-Buddhist poetic anthologies, see Subhāṣitāvali 3313, attributed to a bodhisattva/the Bodhisattva):

kṣaṇasampad iyam sudurlabhā pratilabdhā purușārthasādhanī|

yadi nātra vicintyate hitam punar apy eșa samāgamaḥ kutạ \|

Tr. by La Vallée Poussin (1907: 2 [439]):

"Combien difficile à obtenir cet état béni qui réunit toutes les conditions du bonheur temporel et de la délivrance! Si l'homme n'en profite pas pour réfléchir au salut, c'en est fair pour bien longtemps de pareille rencontre."

$5^{1}$ A possible alternative is to understand dharmayaśa has a dvandva compound, depending on how we interpret 28c. Also cf. st. 8 above.

$5^{2}$ The play on artha/anartha is lost in translation. 
sa ca kramah śokatamasā paryākulamānasasya abhibhūyamānasya dainyena vilupyamānasmṛter ${ }^{53}$ daurmanasyena kutạ̣ syāt | tasmāt kṛ́sodayo nirudaya eva vā śoka iti naivānuvartitavyaḥ |

But how could there be such a course for one who is mentally distressed by the darkness of grief, overcome by depression, of lost mindfulness due to dejection? Hence grief, which indeed brings paltry or no gain, should not be dwelt upon.

$$
\begin{aligned}
& \text { cittasya saṃtāpavivardhanāc ca } \\
& \text { śokānalo duhkhhaphalābhimarśah | } \\
& \text { kutaḥ sukhaṃ cetasi tapyamāne } \\
& \quad \text { samucchrayasyāpi tadāśrayasya || [25] }
\end{aligned}
$$

(ii) Then, because it increases anguish in the mind, the fire of grief is connected with painful results. [For] how could there be comfort when the mind is tormented, let alone in the body, which depends on it? ${ }^{54}$ [25]

iti duḥkhaphalābhimarśo duḥkhātmaka eva ca śokaḥ |

Thus grief is connected with painful results and is nothing but suffering.

sa cāpratisaṃkhyānād anivāryamāṇaprasaraḥ punaranuvṛttyā labdhabala āpyāyamānaḥ ${ }^{55}$ kuvitarkaiḥ pramathya dhairyaśobhāṃ samabhibhūya smṛtị̣ saṃkṣobhayan dehāśritān anilādīn dhātūṃś cetovikāram †anyatathāsaṃ vā† prāṇoparodhinaṃ rogātańkam utthāpayet | tad evaṃ mahātyayatvād apy ananuvṛttikșama eva śokah |

(iii) Moreover, grief, when its spread is not checked for lack of a tranquil consideration, becomes even stronger by nursing it again, feeding on wrong reasoning. It then destroys the distinction of steadfastness, overcomes mindfulness, and disturbing wind and the other bodily humours, distorts the mind, $\dagger \ldots \dagger$ and causes sickness blocking the vital energies (/endangering life). So, because of its being of great danger too, grief should not be dwelt upon.

53 vilupyamānasmṛter] em., vilupyamānah smṛter Ms.

54 This is very likely an allusion to passages such as the famous first two verses of the Dharmapada.

55 āpyāyamānaḥ] st., āpyāyyamānaḥ Ms. 
dharmayaśaḥsapatnabhāvāc ca parivarjya eva dūratah śokaḥ |

(iv) Grief should also be avoided from afar on account of its being an adversary of fame for [dedication to] religious duty. ${ }^{56}$

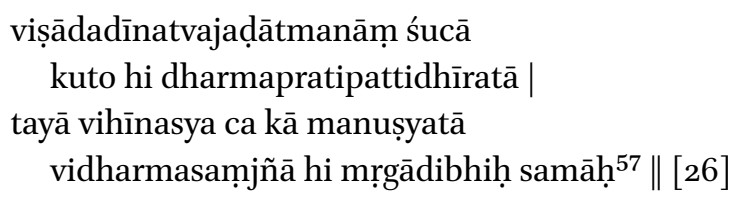

For how could those paralysed by the dejection and depression caused by grief muster the fortitude to undertake religious duty? And if one lacks that [fortitude to undertake religious duty], how can he be called a man? For those lacking the concept of religion are no better than beasts and [barbarians ${ }^{58}$ ]. [26]

na śokam asmāt svamano 'dhiropayet

tathā hi dharmasya bhaved $\mathrm{a}_{[51 \mathrm{r}]}$ ]atkriyā $\mid$

suhṛttamebhyo 'py upakārato 'dhikam

ka eva dharmaṃ ca vimānayed budhah || [27]

Therefore one should not allow grief to dwell in the mind, for by doing so one dishonours religion. And what kind of wise man would dishonour religion, which, from the viewpoint of assistance [it can provide], is superior to even the best of friends? ${ }^{59}[27]$

$5^{6} \quad$ See n. 51 .

57 samāh] em. (Isaacson), samā Ms.

$5^{8} \quad$ That mlecchas are one of the groups covered by the $\bar{a}$ di here can be inferred from st. 2.19

(Ms 3r4):

mleccheșv api pațuryaktir arthakāmasamudyamaḥ |

lakșanam tv idam äryānāạm yeyam dharmānuvartitā $\|$

"Even among the barbarians we find skilful exertion for wealth and pleasure, but the mark of noble ones/Aryans is this: following the Law."

Also see 29c just below, provided that the emendation holds. Cf. Dante, Inferno 26.117-119

(ed. Giorgio Petrocchi, La commedia secondo l'antica vulgata, Milano 1966-1967):

Considerate la vostra semenza:

fatti non foste a viver come bruti,

ma per seguir virtute e canoscenza.

I thank Vincent Tournier for pointing out this conceptual parallel, incidentally a favourite passage of S.Z.

59 Cf. Ms 26r5-26vi: saha pāmnsukrị̣itebhyo 'pi ca prājñebhyạ̣ snehāvabaddhahṛdayebhyo 
virādhya dharmaṃ ca śuco 'nuvartanāt

paratra caiveha ca saukhyakāraṇam |

ka eva vidvān iti kīrtim āpnuyād

balena dhairyasya tad eva saṃtyajet $\|$ [28]

And who could possibly gain fame as a learned man if one injures religion, the cause of comfort both here and in the hereafter, by dwelling on grief? One would do well to give it (i.e., dwelling on grief) up by the power of fortitude. [28]

iti dharmayaśaḥsapatnabhūtaṃ

manaso nirnuda ${ }^{60}$ sādhu śokadainyam |

asadharma ${ }^{61}$ ivāśruviklavākșah

kim amārge parikhedam abhyupaiși || [29]

Thus, please cast aside from your mind the depression of grief, an adversary of fame for [diligence in] religious duty. Why exhaust yourself on a misleading path like a heathen (lit., a man lacking dharma) with eyes swamped in tears? ${ }^{62}[29]$

mitrebhya upakārasamarthebhyah śîlam eva viśisyate, sukhakaratvād iha parataś ca| "Because it provides comfort both here and in the hereafter, morality is indeed superior to friends, even ones with whom one played in the dust [during early childhood], wise ones, whose hearts are loving, and are able to assist [in all matters]."

6 nirnuda] corr., nirnuda Ms.

61 asadharma] em., asaddharma Ms (unmetrical).

62 This is perhaps a reference to Yãjñavalkyasmṛti 3.11:

śleșmāśru (ed. prints śleșmāśr ${ }^{\circ}$ ) bāndhavaị̣ muktam preto bhuñkte yato 'vaśaḥ|

ato na roditavyam hi kriyāh kāryāh svaśaktitah $\|$

"Since the departed powerlessly swallows the mucus and tears emitted by [the grieving] relatives, there should be no wailing [for the dead]; instead, the [funerary] rites should be performed according to means."

Cf. Raghuvamiśa 8.86:

apaśokamanāḥ kuțumbinīm anuĝ̣hn̄iș̣va nivāpadattibhị̣|

svajanāsru kilātisantatạ̣ dahati pretam iti pracakșate \|

"[Instead,] show favour to your [departed] wife by bestowing the mortuary offerings with a mind that has cast grief aside. For they (i.e., dharmaśāstra experts) say that the incessant stream of kinsfolk's tears pains (lit., burns) the departed."

Both Vallabha and Mallinātha cite the Yãjñavalkya verse in their commentaries. 
āpadi samupanatāyāṃ

yaś ca vidhir naiva tatpratīkāraḥ |

niṣkevalaṃ śramaphalạ̣

prājñas tam anubhramet ka iva $\|$ [3o]

As for the customs prescribed regarding befallen misfortune (i.e., death), ${ }^{63}$ they do not serve as an antidote to [grief]. What kind of wise man would follow them in error, when they result in nothing else but exhaustion? [30]

tasmād dhairyam ālambya śrutānusāravyāpāre niyujya smṛtiṃ lokasvabhāvapratyavekṣayā samunmīlya prajñācakṣuh sarvaprakāram aparigrahakṣamaṃ tyaktum arhasi śokadainyam |

Hence, you would do well to resort to fortitude, to turn your attention to deeds in conformity with what you heard from scripture, to open the eye of wisdom by carefully analysing the nature of the world, and to give up the depression of grief, which should not be adopted no matter how one looks at it.

paśyatv āyuṣmān |

Behold, good sir!

pathika iva kuto 'pi ko 'py āgato yady ayaṃ mārgakhedād iva tvatsamīpe muhūrtasthitah prasthitạ̣ kvāpi kiṃ tatra śokānuvṛttyā svabhāvo 'dhvagānām ayam |

yadi ca tava guṇodayair vatsalībhāvam āpāditaḥ svārthapāṇ̣̣ityam asyaitad atyāryabhāvāt tu tat tvaṃ kṛtam manyase ko hi nairgunyadagdham janam snihyati |

yadi ca tava na vetty ${ }^{64}$ avasthām imāṃ śokajāṃ saṃbhramavrīịasaṃtāpavaśyo viditvā na vā jāyate ${ }^{65}$ naiti cājñāṃ yamasyāpy atikramya kị̣ vatsalas tarhy asau |

63 It is unlikely that here the appaddharmas are meant, although the author is aware of them (e.g. st. 7.54, Ms 39v5-4or1; st. 7.56, Ms 4or1-2). The most likely referent of vidhi is the complex set of rules prescribed for impurity following death in the family (āśauca) and the śrāddha rites. For these, see Kane 1953: 179-551.

64 vetty] em., vety Ms.

65 A possible conjecture might be na vojāyate (=vāa +ojāyate): "he does not become eager to [return], subject to' etc. 
atha tu vidhir alabhya evāyam evaṃ gate ko guṇaḥ śokadainyena tulyārtisaukhyam janaṃ bādhitum yat tato 'nantaram kāryam āryeṇa tat kāryam eșa ${ }^{66}$ kramah $\|$ [31]

He, much like some traveller, arrived who knows whence, dwelt by your side for a short while as if fatigued by the road, and now set out onwards who knows where-so why dwell on grief?67 This is the nature of travellers. And if he took to you because of your lofty virtues-well, that simply means that he knew what was best for him. You may think that he did so on account of his most noble nature-but who will love a man who is cursed by lack of virtues? ${ }^{68}$ Moreover, does he truly love you, if he is not aware of this state of grief of yours? Or perhaps he is aware-but then why does he not become subject to zeal, shame, and pain, and return [to you], transgressing even the command of the Lord of Death? But if this is impossible - and it is - what gain is there in tormenting others ${ }^{69}$ who share both your sorrow and happiness with the depression of grief? Do whatever a noble man needs to do after [death] — this is the proper order of things. [31]

tasmāc chokaṃ viș̣ja manaso naișa śokasya kālaḥ

kālo hy eșa tvarayati janaṃ dharmatattvapravṛttyai |

yad yat kṛtyaṃ svahitaniyataṃ tatra tatrāpramāda-

vyāpāras te bhavatu manasas tattvasiddhipratișțheh || [32]

66 eșa] conj., eva Ms.

67 Cf. Buddhacarita 9.35: yathādhvagānām iha saṃgatānām kāle viyogo niyatah prajānām |

Tr. by Johnston (1936: 130):

"The separation of creatures who have come together in this world, as of wayfarers, is inevitable in the course of time. What wise man then would cherish grief, when forsaken by those who are only his kindred in name?"

Cf. Hitopadeśa st. 4.75 (= Sūktiratnahāra st. 197.5, attributed to the Brhatkathā): yathā hi pathikaḥ kaścic chāyām āśritya tișțati (in the anthology: viśramet) | viśramya ca punar gacchet tadvad bhütasamāgamahn $\|$

Tr. by Törzsök (2007: 500-501):

"Just as a traveler seeks shelter under a tree, stays in its shade to have some rest and then leaves it again, so too does one living being encounter another."

68 Note that $\sqrt{s n i h}$ should normally attract locatives (or genitives), not accusatives; while it is tempting to emend to ${ }^{\circ}$ dagdhe jane, I have decided to keep the original reading, perhaps a true witness of the author's usage.

69 Note the unusual construction of ko gunah with an infinitive, not an instrumental. 
Dispel therefore grief from the mind! This is not the time for grief. Time (/Death) itself impels men to practice the essence of the doctrine. Become of unfailing action in whatever needs to be done for your own benefit, so that [your] mind may become established ${ }^{70}$ in the realisation of truth! [32]

avetya mṛtyor anivāryavīryatāṃ

calasvabhāvatvam avekșya cāyuṣaḥ |

śucaś ca tatra pratikārabāhyatām

hite sva eva prayateta paṇḍitah || [33]

Having understood the irresistible power of death, having seen the fickle nature of [a man's] lifespan, and having realised that grief is no antidote for [either of] these, a wise man should strive only for his own benefit. [33]

tat punah svahitạ̣ kriyamāṇaṃ puṇyakriyāvastutrayasamāśrayāt saṃ ${ }_{[51 v]}$ pādyeta laukikam | yathoktaṃ bhagavatā |

\section{trīnìmāni}

\section{sūtram uktvā vācyam |}

As for one's own benefit, when (/if) performed by relying on the three bases of meritorious acts, it will bring about worldly [benefit]. As the Lord taught:

"These three ..."

After having recited the sūtra, ${ }^{71}$ one should say:

tatra dānam anekaguṇasaṃpādi tasmād ātmahitam | tadyathā |

$70 \quad$ The word pratișthi is quite rare if not idiosyncratic and therefore the interpretation is somewhat uncertain.

71 There are several candidates for the source of the textus, e.g. an equivalent of the $P u$ ññakiriyavatthusutta (It 6o, 51-52; AN 8.36, iv.241-243). Also cf. Sangitisuttanta (DN 33, iii.218,5-7): Tīni puñña-kiriya-vatthūni. Dāna-mayam puñña-kiriya-vatthu, sïla-mayam puñña-kiriya-vatthu, bhāvanā-mayam puñña-kiriya-vatthu. 
ājñādiptir

\title{
iti vācyam |
}

Among these, (i) charity begets numerous virtues and thus one's own benefit. To wit: [Here] one should recite [the verse] beginning with

\author{
"Lustre of authority, ..."72
}

tathā śilam | yathoktam |

kulād vittād alaṃkārāt |

(ii) It works in the same way with morality. As [we have] taught [above]:

“[Morality is far superior] to: family lineage, wealth, ornaments, ..."73

tathā bhāvanā brahmalokopapattyādisaṃpādanīty abhihitam |

$7^{2}$ In the present work, this stanza is the pericope verse of the fifth option for sermons on charity, listing eleven karmic rewards (st. 3.57, Ms 14r2):

ājñādīptir bhogasampat prakrșțā rūpaudāryam varṇamādhuryam ojah |

vāk saubhāgyam kāntir ārogyam āyus tattaddānād iștam ișțạ̣ phalạ̣ ca \|

"By [practising] various kinds of charity [one gains]: (i) lustre of authority, (ii) most excellent abundance of enjoyments, (iii) noble beauty, (iv) exquisite looks, (v) strength, (vi) eloquence, (vii) welfare, (viii) handsomeness, (ix) health, (x) long life, and (xi) all that he desires."

The same stanza is found in the *Subhāṣitaratnakaraṇdakakathā attributed to Āryaśūra (st. 22) and as st. 4.2 in the Dvāviṃśatyavadānakathā. (For the relationship between these two works, see Formigatti 2016: 120-123.) In light of our anonymous author's elaboration of this verse, we can possibly improve Hahn's superior edition (1983b: 333 ) in two places: tattaddānād is a compound, whereas vāksaubhāgyam is not. Here $v \bar{a} k$ is glossed with 'eloquence' (pratibhā/pratibhāna) and saubhāgya with 'welfare' (bhāgya, saubhāgyalakșmī).

73 In the present work, this is the beginning of a pair of stanzas (5.32-33, Ms 24v1-2) listing fourteen items to which morality is superior:

kulād vittād alạ̣kārād aiśvaryād rūpasampadaḥ|

vilepanebhyo hlādibhyah sthānād yānāt tathāyuṣah $\|$

vaśīkaranamantrebhyah svajanān mitrasamśrayāt |

laukikïbhyaś ca rakṣābhyaḥ śilaṃ dūram viśișyate \|

"Morality is far superior to: (i) family lineage, (ii) wealth, (iii) ornaments, (iv) sovereignty, (v) the fortune of beauty, (vi) ointments, (vii) things that bring comfort in heat, (viii) postures/places, (ix) vehicles, (x) lifespan, (xi) subjugating mantras, (xii) kith and kin, (xiii) association with friends, and (xiv) worldly prophylactic magic." 
(iii) And in the same way with contemplation, which is taught to bring about benefits such as being born in the World of Brahmā. ${ }^{74}$

evam anekavyasanakaṇṭakasañkaṭaṃ vā saṃsāram anupaśyatā sarvaduhkhapraśamābhilāṣiṇā caturāryasatyadarśanāya dhyātavyam | yathoktaṃ ${ }^{75}$ bhagavatā

ye keci bhikkhave imaṃ duḥkhaṃ ti yathäbhütam prajānanti te neva nirayam gacchanti $\left.\right|^{76}$

iti vistarah | atra pūrvām ${ }^{77}$ eva pracarcām ${ }^{78}$ uktvā vācyam |

Thus, alternatively [to worldly benefit], upon seeing that transmigration is nothing but a heap of thorn-like predicaments, he who desires the allaying of all suffering should meditate to realise the Four Noble Truths. ${ }^{79}$ As the Lord taught:

"Oh monks! Whosoever realise as it truly is that all this is suffering will not fall into the realms of hell ..." ${ }^{\prime \prime}$

etc. Here, after having recited the previous discussion, ${ }^{81}$ one should say:

dṛsțvāryasatyāni yathāvad evaṃ

nāpnoti bhūyo vinipātaduḥkham |

74 As far as I can tell, the present work does not deal with the benefits of contemplation; the author must have had some other text/s in mind.

75 yathoktam] em., yaktoktam Ms.

76 The Sanskritic spelling duhkham is attested in Sammatìya-connected MIA sources, e.g. the Go Xoai inscription from Southern Vietnam (Skilling 1999) and the Devni Mori inscription from Gujarat (Tournier, forthcoming); neva is found in this form in another textus, Ms 19v4.

77 pūrvām eva] $\mathrm{Ms}^{\mathrm{ac}}$, pūrvoktam eva Mspc

78 pracarcām] st., pracarcam $\mathrm{Ms}^{\mathrm{pc}}$, pracarccām $\mathrm{Ms}^{\mathrm{ac}}$

79 Or: "the Four Truths of the Noble One (/Ones)"; cf. Norman 2008.

8o Untraced. While niraya normally refers to the hells (naraka) only, the subsequent stanza seems to suggest that for the author it meant the three durgatis/apāyas, i.e., the realms of hells, ghosts, and animals.

81 It is not quite evident which discussion the author refers to here. The intention of the corrector (it is difficult to ascertain whether this was the primary scribe or not) is not entirely clear, as the noun is normally feminine ( $\operatorname{racarc} \bar{a}$ ) and the masculine is only extremely rarely attested. I have therefore retained the ante correctionem reading in the constituted text. 
doșā hi ye durgatihetubhūtās

tān satyadarśī prajahāti sarvān $\|$ [34]

Having thus seen the Noble Truths ${ }^{82}$ as they truly are, one never returns to the pain of lower rebirths. For the seer of the Truth[s] obliterates all the vices which are the cause of lower rebirths. [34]

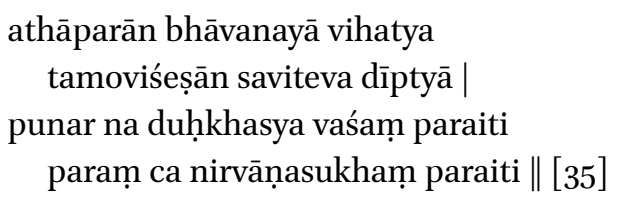

Next, having dispelled [all] other [kinds of vices] by the power of contemplation, just like the Sun [dispels even] the deepest darkness with its blaze, one is never again enslaved by suffering, but achieves the supreme bliss of Nirvāna. [35]

itīmāni cāpriyāṇy anityāni calāny anātyantikasamavadhānāni saṃpaśyatā saṃvega eva manasy upabṛmhayitavyạ̣ | na śokasaṃvignacitto hi śreyaḥpratipattikarmaṇyo bhavati | tadyathānuśrūyata ity atrāyogṛhajātakam uktvā vācyam |

So, having contemplated all these unpleasantnesses as impermanent, transient, connection with which is intermittent, one should cultivate in one's mind only enthusiasm ${ }^{83}$ [for the spiritual path]. For while one's mind is overwhelmed by grief, one is not suitable (/fit/competent/able) for the practice to achieve the

$82 \quad$ See n. 79 .

83 On this arguably untranslatable term, see Acri 2015. Inducing samvvega is mentioned as one of the aims of delivering sermons in stanza st. 1.10 (Ms 1v3-4):

atah prasādasamvegaharșaṇādiprayojanāḥ |

vakṣye parikathāś citrāḥ śarañādisamāśrayāh \|

"I shall therefore teach a variety of sermons which have as their aim calmness ( $\mathrm{pra}$ sāda), enthusiasm (sampvega), gladdening (harșaṇa), and so forth, beginning with [the merits of] taking refuge [in Buddhism]."

This is not very far from the stated aims of classical rhetorics and their application in a Christian context. Rhetorical/homiletical guides frequently claim that the three aims were defined by Cicero in De Oratore (although the wording there is slightly different): to teach/instruct (docere), to delight/please (delectare), and to move/persuade (movere); cf. also Holmes 1755: 1. 
summum bonum. As it is heard - and here, after having recited the Birth Story of the Iron House, ${ }^{84}$ one should say:

avāryavīryeṇa kṛtāntavahninā

pradīptam evaṃ prasamīkṣya sarvatah |

jagan nirākrandam anātham āturam

śamāya saṃvegapathaṃ vrajed budhah || [36]

Having thus beheld from every angle the world set ablaze by the fire of death whose power cannot be checked, without fellow men to cry to, without protector, distressed, the wise man should take to the path of enthusiasm towards Peace. [36]

\section{aparaḥ kalpaḥ |}

(III) [I shall now explain] another disposition:

sarvatrāvyāhatam jñānam

uttamāṃ ca hitaișitām |

prājñah saṃsmṛtya buddhānāṃ

nābhimanyeta tadvacah \|| [37]

A wise man should not disrespect the words of the buddhas, after having brought to mind their knowledge, which is unimpeded with regard to all [knowables ${ }^{85}$, and altruism which is supreme. [37]

jñānena yukto 'pi hiteșv ayukto

hitodyataḥ syāc ca na buddhimān yah |

vacas tayor nāpy asamīkṣya kuryāt

prāg eva tābhyāṃ rahitaś ca yaḥ syāt || [38]

Some might possess knowledge but not be interested in altruism and others may be altruistic but lacking intelligence. One should not without due examination follow the words of either, let alone one who is devoid of both. [38]

84 That is to say, Āryaśūra's Jātakamālā no. 32.

85 See 39a below. Also cf. Mahāyānasūtrālaṃkāra 9.72ab, 20.47c; Abhidharmakośabhāsya ad 7.3ocd; Tattvasamgraha 3420 . 
jñeyeșu sarveșu tu yasya buddhir

loke hitādhyāśayavat pravịttā|

avyāhatā tasya vacaḥpravṛtti- 86

vimarśakhedopagamena ko 'rthah \| [39]

Now, [the Buddha is such an authority] whose mind is unimpeded with regard to all knowables and functions together with an (/just like his) intention to bring benefit ${ }^{87}$ to the world. So what is the point of bothering ourselves with the toil of examining ${ }^{88}$ the ways of his word? [39]

[52r] vinivartitāś ca bhagavatā śokānuvṛttiprasaṅgavyākulamanaso vineyā niṣprayojanād duhkhadaurmanasyopahartur apahartur guṇānāṃ śokāt |

The Lord himself steered away his followers from grief which is [not only] pointless, [but also] causes suffering and dejection, and robs people of their virtues, when their minds were overcome with dwelling on grief.

tadyathā duhitṛśokārtā urvarī sthavirī | yathoktam |

$$
\text { ammo jōva me tti krandasi }
$$

(i) For example, the venerable nun Urvarī, tortured by grief for her daughter. As it was taught:

"You wail «o my Jì $\bar{a} \gg . . . " 89$

tathā putraśokaśalyavyathitahṛdayā vāsișthisthavirī putraśokān nivartitā | yathoktam |

yassa māggaṃ na jānāsi āgatassa gatassa vā |

$86{ }^{\circ}$ pravrittio ${ }^{\circ}$ em. (Isaacson), ${ }^{\circ}$ pravrịttir Ms.

87 The matup-ending compound hitādhyāsayavat does not construe smoothly, hence the interpretation is somewhat tentative.

88 The word ${ }^{\circ}$ imarśa $a^{\circ}$ here echoes asamiksya in $38 \mathrm{c}$.

89 Cf. Thī no. 33, stt. 51-53. Her name in Pali is Ubbirī, Jīvā is her daughter. The form cited here is slightly different, having a personal possessive pronoun and missing vanamhi "in the forest" before the verb. The vocative should most likely be corrected to *jī $\bar{a}$. For a list of problems concerning the form and interpretations of this verse, see Masset 2005: 119120 . 
(ii) Or the venerable nun Vāsișțhī, whose heart was pierced by the arrow of grief for her son was steered away from grieving for her son. As it was taught:

The way by which he came you cannot know, nor the path by which he went ... $^{90}$

tathā mātṛśokārtas tathāgatavacanānusmṛtyā vyavasthāpayann ātmānaṃ rājā prasenajit tasya kramasyānujñānād vistareṇa ca tasyārthasya pradarśanād vinivartitạ̣ śokānuvṛtter bhagavatā | yathoktam |

ayyā me bhante mātā kālagatā |

\section{iti sūtram anusmartavyam |}

(iii) Or king Prasenajit, tortured by grief for his mother, who composed himself after having called to mind the word of the Tathāgata; the Lord, who first assented to that course and then explained extensively the statement's meaning, steered him away from dwelling on grief. As it was taught:

"Venerable one, my respected mother passed away ..."

\section{and call to mind [the rest of] the sütra. ${ }^{91}$}

90 Cf. Thi no. 5o, stt. 127-132, the only difference is that the Pali has the mora-correct maggam (note, however, that Sammatìya-related MIA does not always observe the law of three morae; see Tournier, forthcoming). In the Pali version this set of verses is attributed to Pațācārā, and is not the one by Vāsițțhī, which is Thī no. 51, stt. 133-138. It is possible that something dropped out in our copy, as the clumsy repetition of putraśoka in the introductory sentence is suspicious. For Vāsițthī, see Durt 2001.

91 Cf. Ayyakāsutta (sN III.3.2, i.96,31-97,33): Ayyakāa (var. ayyikā) me bhante kālakatā jinnnāā vuḍ̂a mahallikā, etc. There seems to be a rare(r) variant of the textus here, as the departed lady is usually mentioned as the king's grandmother. The Chinese parallels and an Inner Asian fragment are listed in Chung 2008: 217. For a Sanskrit fragment from Central Asia, see Hartmann 2017 (especially p. 96, n. 10 for sources attesting the same bifurcation, for which also see Willemen 1999: 8-9 as well as the Chuyao jing, Taishō no. 212 (IV) $621 a 18$ which also has 'mother' here). For another version of this sūtra, see Tridandamāla $84 \mathrm{r}^{-8} \mathrm{5}_{\mathrm{vl}}$ (here: $\left.\bar{a} r y i k \bar{a}\right)$. Here, the king regains his composure after calling to mind the $\mathrm{Bu}-$ ddha's word that no being is exempt from death (sarveșām sattvānām sarveșāṃ prānināạn sarveșām bhūtānām maraṇāntam jōititam maraṇaparyavasānam, nāsti jātasyāmaraṇam). The Buddha echoes the general statement (which is likely what our somewhat obscure tasya kramasyānujñānāt means) and then elaborates on it with a long list of beings, beginning with kṣatriyas and up to tathägatas. 
tathā sthavirāryānandas tathāgataḥ parinirvāsyatīti śokenābhibhūyamānacetā nivāritah śokānuvṛtter bhagavatā

alam ānanda mā śoca

ityādi |

(iv) Or the elder noble Ānanda, when his mind was overcome with grief because he thought that the Tathāgata was about to reach complete Nirvāna, was steered away from dwelling on grief by the Lord [with the words] beginning with:

"Enough, Ānanda, do not grieve ..."92

tathā tattannaimittikaśokaśalyoddharaṇārtham sattvānāṃ parānukampakena bhagavatā pañcālambhanīyāni deśitāni yāni pradarśayatā sthavirāryanāradena muṇḍarājo bhāryānaimittike śokapan̉ke 'vasīdann uddhṛtaḥ | yathoktam |

pañcemāni mahārāja alambhanīyāni

\section{iti sūtram uktvā vācyam |}

(v) Or again, the Lord, who took pity on others ${ }^{93}$ taught the Five Unobtainables for sentient beings to pluck out the arrows of grief caused by one thing or another. Explaining these five, the elder noble Nārada rescued king Munḍa, who was sinking into the swamp of grief caused by the death of his wife. As it was taught:

"Great king, these Five Unobtainables ..."

and after having recited [the rest of] the sütra, ${ }^{94}$ one should say:

92 Cf. Mahāparinibbāṇasuttanta (DN 16, ii.144,10): Alaṃ Ānanda mā soci (var. soca) mā paridevi (var. paridevā). etc.

93 Alternatively, although less likely: "whose compassion is supreme".

94 Cf. Näradasutta (AN 5.50, iii.57-63). The five things which are unobtainable for anyone are: that what is subject to aging ( jarā) may not age, and then the same for sickness (vyādhi), death (marana), destruction (kșaya), loss (nāśana). Towards the end of the text, the sūtra is called the sokasallaharano dhammapariyayyo, which is echoed by the introductory sentence here (tattannaimittikaśokaśalyoddharaṇārthaṃ). 
vineyacitteșv iti śokavahnim

udīryamāṇaṃ kuvitarkavātaiḥ |

nopekșate sma pravaro munīnāṃ

vācāmbubhis tạ̣ śamayāṃ babhūva || [40]

Thus did the best of sages not ignore the fire of grief in the minds of followers fanned by the winds of wrong reasoning; he extinguished it with the water of his words. [40]

vivardhamānaṃ hṛdayeșv anartham

kathaṃ hy upekșeta muniḥ pareșām |

sattveșu putreșv iva yasya nityam

paro hitādhyāśayasaṃniveśah \| [ [41]

For how could the Sage ignore misfortune growing in the hearts of others, when his supreme intention to benefit sentient beings as if they were his sons is constant? [41]

naivānujajñe munisattamaś ca

yasyānuṿ̛ttiṃ sa mahākṛpāluḥ|

prājñas tam abhyāpatitam ka eva

śokaṃ manonirvișayaṃ na kuryāt || [42]

And since the Chief of Sages, he of great compassion, did not endorse dwelling on grief, what kind of wise man would not put it out of his mind ${ }^{95}$ once it has assailed him? [42]

kaḥ punas tadupāya ity ucyate |

But what is the method for that? We explain:

vijñāya niṣyandam imaṃ priyasya

tatrānurāgaṃ na samādadhīta |

jagatpravṛtter ati ${ }^{96}$ cañcalatva-

svabhāvadoṣaṃ samavekṣamāṇah || [43]

95 This collocation is quite rare: it is seen only in Āryaśūra's Pāramitāsamāsa (st. 2.5d) and once in Kālidāsa's Kumārasaṃbhava (st. 5.38c).

$96 \mathrm{ati}^{\circ}$ ] conj. (Isaacson), iti Ms. 
Knowing the [inevitable natural] outcome of something dear (i.e., that it shall pass), one should not become attached to it, realising full well that the fate (/doings/matters) of the world bear the inherent defect of being extremely fickle. [43]

evaṃ hy uktaṃ bhagavatā |

$y e_{[52 \mathrm{v}]}$ keci śokā paridevitam $v \bar{a} \mid$

\section{iti gāthādvayam |}

priyāto jāyate duḥkham |

iti gāthātrayam | tathā |

yasya grāmaṇi cattāri prìyāṇi cattāri tasya duḥkhāni|

For this is what the Lord taught: [here recite] the two stanzas beginning with

"Whatever grieving cries and lamentations ..."

[and/or] the three stanzas beginning with

"From attachment arises suffering ..."98

Moreover,

"O chieftain! He who has four attachments has four kinds of suffering ..."

yathā coktam |

asitapītakhāyitasāyitasseso nāgila nișyando ${ }^{100}$ ya idam uccāraprasrāvo iștassa kāṃtassa |

97 Dharmapada (Patna/Saindhava) $84-85$. For the designation Saindhava, see Dimitrov 2020.

98 Dharmapada (Patna/Saindhava) $7^{2-74}$.

99 Untraced.

100 nișyando] st., niṣyamịno $\mathrm{Ms}^{\mathrm{pc}}$, nișaṃdo $\mathrm{Ms}^{\mathrm{ac}}$ 
Moreover, as it was taught:

"Nāgila, the outcome of something preferred and loved when eaten, drunk, consumed, and tasted is but faeces and urine ..."101

tasmād ucyate |

Hence it is said:

śokāyāsavișādadainyavirasaṃ yad viprayoge priyaṃ

tasmād ātmavatāṃ tad apriyam atas tadvarjanaṃ ca priyam |

bālānāṃ tu patanggalolamanasām āsvādamātrekṣiṇāṃ

tadvad vipriyajātam apy upaharan naivāpriyaṃ vipriyam || [44]

Since [something or someone] beloved at the time of separation becomes insipid (/painful) with grief, weariness, depression, and affliction, for the self-possessed it is not beloved, and so forsaking it is what is beloved. Conversely, for the immature, whose minds move hither and thither like moths, who heed nothing but relishing [momentary pleasures], even if in the meanwhile they collect a heap of unpleasantness (/grief), no unpleasant thing (i.e., grief etc.) is not loved. [44]

api ca | tad evaṃ priyanidānaṃ śokādiduḥkham avetya na tatra snehaprasaṅgam anubhramet |

Moreover: so, having thus understood that the suffering of grief and so forth is rooted in [things and beings] loved, one should not erroneously become attached to love.

api ca |

$$
\begin{aligned}
& \text { muhūrtaramyeșu calātmakatvād } \\
& \text { analpaduḥheṣu viyogakāle | } \\
& \text { ko nāma kurvīta manaḥprasañgaṃ } \\
& \text { svapnopameṣu priyasaṃgameṣu || [45] }
\end{aligned}
$$

101 Cf. Nāgitasutta (AN 5·30, iii.32,1-2): Asitapittakhāyitasāyitassa kho Nāgita uccārapassāvo, eso tassa nissando. 
Who could possibly attach his mind to meetings with loved ones, [fleeting] like a dream, when they, being transient, can be enjoyed but for a moment, and cause much suffering at the time of separation? [45] $]^{102}$

yathoktam paramarșiṇā |

supinena yathāpi sañgatam

\section{iti gāthādvayam |}

As the Supreme Sage taught:

"Whatever he met with in a dream ..."

[and here one should recite the rest of] the two stanzas. ${ }^{103}$

yaś ca nāma pratīkāro

na bhūto na bhavișyati |

yasyām āpadi kas tatra

tam arhaty anuvartitum $\|[46]$

Now, who could possibly dwell on something (i.e., grief) that in the same kind of calamity never was nor will ever be an antidote? [46]

tad dhairyam ālambya jahīhi śokaṃ

mārgo na khalv eșa bhavadvidhānām |

parikșakasyā ${ }^{104}$ tmavatạ satas te

girer ivādhairyam ayuktarūpam $\|$ [47]

102 Cf. Buddhacarita 9.33cd: yat svapnabhūteșu samāgameșu saṃtapyate bhāvini viprayoge \| Tr. Johnston (1936: 129): “[...] since unions are fleeting as dreams and parting is certain."

103 Cf. Jarāsutta (Sn Iv,6.4-5, stt. 807-808, 158-159):

Supinena yathà pi sañgatạ̣ pațibuddho puriso na passati,

evam pi piyāyitam janam petạn kālakatam na passati.

Diț̣̂ā pi sutā pi te janā, yesaṃ nāmam idaṃ pavuccati: nāmam evāvasissati akkheyyam petassa jantuno.

Tr. by Norman (1992: 94):

"Just as a man, awakened, does not see whatever he met with in a dream, even so one does not see beloved people when they are dead and gone. Those people are seen and heard of, whose name is 'so and so'. When he has departed, only a person's name will remain to be pronounced."

104 parīkșakasyāo] em., parīkșya kasyāo ${ }^{\circ}$ Ms. 
So, take to fortitude and abandon grief! Truly, this is not the path for people like yourself. Lack of fortitude does not befit you, a discerning, selfpossessed, good man, any more than it would a mountain. ${ }^{105}$ [47]

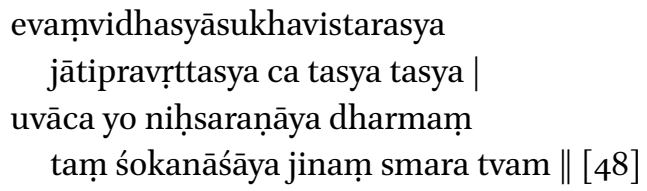

In order to remove grief, call to mind the Victor, who taught the Doctrine to escape from both this heap of sorrow and whatever other kinds [of sorrow] that follow [a man] from birth! [48]

yathoktam |

iti pi so bhagavā |

As it was taught:

"Thus indeed is the Lord ..."106

iti pramodaṃ guṇasamsmṛ̣tir muneh karoti punyocchrayasiddhikāraṇam |

atas tayā śokatamo vyudasyate sahasraraśmiprabhayā yathā tamaḥ || [49]

105 Cf. Buddhacarita 8.83ab: tyaja naravara śokam ehi dhairyaṃ kudhṛtir ivārhasi dhīra nāśru moktum | Tr. Johnston (1936: 121): "Cease grieving, O best of men, return to firmness; you should not, O steadfast one, shed tears like a man without self-control." Cf. Raghuvamiśa st. 8.90:

na prthagjanavac chuco vaśaṃ vaśinām uttama gantum arhasi $\mid$

drumasānumatoḥ kim antaram yadi vāyau dvitaye 'pi te calāh $\|$

"It does not befit you, greatest of men of self-control, to yield to grief like some commoner. What would be the difference between a tree and a mountain if both were to be swayed by the wind?"

106 Locus classicus unclear (possibly the Dhajaggasutta?). On this very popular formula, recited even today, see Bechert 1988: 8-9 passim, or most recently Hinüber 2020: 18-21. See also the Vimalaprabhā (vol. 1, p. 31; tr. in Newman 1987: 323-324), which specifically claims that it is in the 'language of Magadha': iha prathamam tāvat śrāvakanaye Magadhabhāṣayā dharmadeśanā pițakatrayādau tadyathā «iti pi so bhagavā sammāsambuddho vijjācaranasampanno sugato lokavidū anuttaro» |. In his notes (tr. in Newman 1987: 361), $\mathrm{Bu}$ ston rin chen grub adds the 'language of Sindhu'. Also cf. Tridandamālā no. 4, 6v-7r and no. 37, 103v-104v (Matsuda 2020b). 
Calling to mind thus the virtues of the Sage brings joy, the cause to accomplish the growth of merit. Thus, by that calling to mind the gloom of grief is dispelled, just as darkness by the light of the Thousand-rayed [Sun]. [49]

dinātyaye ca pravij̣̣mbhate punar

divākarasya prabhayā hataṃ tamaḥ |

muner guṇānusmṛtibhāvanoddhṛtaṃ ${ }^{107}$

na jāyate śokatamaḥ punạ̣ punạ̣ \|| [5o]

However, when the day slips away, the darkness that had been dispelled by the light of the Sun appears once again. But the gloom of grief removed by cultivating the recollection of the Sage's virtues never returns. [50]

yathoktam |

cha imā bhikkhave anussatīyo |

As it was taught:

“Oh monks! There are six Recollections ..."108

tasmāt smṛtiṃ jinaguṇeșu niveśya saumya

śokaṃ jahīhi vipulaśramaduhkhamūlam |

snehāt samānasukhaduhkhham avekṣamāṇo

bhaktam janam svaja ${ }_{[53 r]}$ nam eva suḥ̣jjanam ca \| [51]

Friend! Become mindful of the virtues of the Victor and abandon grief, the root of much toil and suffering, being considerate of people devoted to you, who share both [your] pleasure and [your] pain because of [their] love [for you]: your kinsfolk and friends! ${ }^{109}\left[5^{1}\right]$

vij̣̣mbhamāṇo hi yathā divākare

karoti rāhur jagad ākulākulam |

107 oddṛtam] em., ${ }^{\circ}$ oddhṛtim Ms.

108 Cf. Anussatițthānasutta (AN 6.25, iii.312-314). The six in Pali are buddhānussati, dhammānussati, sañghānussati, sīlānussati, cāgānussati, and devatānussati (i.e., the recollection of the Buddha, the Dharma, the Sangha, morality, generosity, and deities).

109 Cf. 3 cd and 31 d above. 
cidāśrayaṃ $^{110}$ śokatamas tathā janaṃ
yato na tan marṣayituṃ tvam arhasi $\|\left[5^{2}\right]$

For just as Rāhu expanding on [the orb of] the Sun [as if devouring it] makes the world overcome with panic, so does the gloom of grief festering in the mind; thus you would do well not to tolerate it. [52]

vahnir yathā bhavanamūrdhani vardhamāno

vyādhir yathaiva ca śarīram abhiprapannah |

āsīivișaś ca bhavane samupekṣyamāṇah

śokas tathā manasi nāyam ato 'nuvartyaḥ || [53]

Like fire spreading on top of one's house, like a disease that has seized one's body, like a venomous snake inside the house unnoticed—such is grief in the mind. Hence one should not dwell on it. [53]

apārthakaś ceti na tạ̣ bhajed budhaś111

ciram ruditvāpi hi ko guno bhavet |

jagatsvabhāvaṃ vigaṇayya cedṛśam

vimokṣamārgonmukhamānaso bhavet || [54]

Moreover, it is of no use, so a wise man should not entertain it. For even if one sobs for long, what could be the benefit? After having reckoned with the nature of the world being thus, one should turn the mind to the path of liberation. [54]

yathoktam |

ekāyanah pracarcyah |

As it was taught:

"The One Way should be studied intensively"12,"113

\footnotetext{
110 cidāśrayaṃ] em. (Isaacson), vedāśrayaṃ Ms (alternatively, emend to a rarer vidāśrayaṃ).

111 budhaś] em., buddhaś Ms.

112 Or: "One should start investigating the One Way", depending on which flavour of the upasarga (prakarșena or ädikarmaṇi, unless it is svārthe) was meant in the original context.

113 Untraced.
} 
Appendix 1: List of Metres Employed in ch.11

Note: the metres in bold occur only in this chapter.

- anuștubh:1, 2 (pāda a = bha-vipulā), 3, 22, 37, 46

- aparavaktra/vaitālīya: 4

- āryā: 30

- indravajrā: 34, 42

- upajāti (indravajrā+upendravajrā): 5-8, 10, 13, 18-20, 23-25, 38-41, 43, 45, 47, 48

- upendravajrā: 35

- dạ̣daka: 31

- pramitākșarā: 9, 15

- mandākrāntā: $3^{2}$

- mälabhäriṇī: 29

- vasantatilakā: 51,53

- vamśasthavila: 12, 17, 21, 26-28, 33, 36, 49, 50, 52, 54

- viyoginī (a.k.a vaitālīya/sundarī): 14

- śārdūlavikrị̣ita: 44

- śälinī: 16

- siṃhapuccha: 11

Appendix 2: Location of Folios in the Tucci Archive

$$
\begin{aligned}
& \text { 49r }=\text { BBBo9ooo1.jpg folio } 4 \\
& 49 \mathrm{~V}=\text { CCCo40001.jpg folio } 12 \\
& \text { 5or }=\text { BBBogooo1.jpg folio } 5 \\
& 5 \text { ov }=\text { CCCo40001.jpg folio } 13 \\
& \text { 51r } \quad=\text { BBBogooo1.jpg folio } 6 \\
& 51 \mathrm{~V}=\text { CCCo40001.jpg folio } 14 \\
& 5^{2 \mathrm{r}}=\text { BBBo9ooo1.jpg folio } 7 \\
& 5^{2 \mathrm{~V}}=\text { CCCo40001.jpg folio } 15 \\
& 53^{\mathrm{r}}=\text { BBBo9ooo1.jpg folio } 8
\end{aligned}
$$




\section{References}

\section{Primary Sources: Sanskrit}

Abhidharmakośabhāṣya: Abhidharmakośabhāṣyam of Vasubandhu. Edited by Prof. P. Pradhan. Revised Second Edition with Introduction and Indices Etc. by Dr. (Mrs.) Aruna Haldar. Tribetan [sic] Sanskrit Works Series Vol. VIII. Patna: Kashi Prasad Jayaswal Research Institute, 1975.

Kumārasambhava: Ka'lida'sa's Kumârasambhava. Cantos I-VII. Edited with the commentary of Mallina'tha, a literal English translation, Notes and Introduction by M.R. Kâle. Second edition. Thouroughly [sic] revised and enlarged. Bombay: The Standard Publishing Co., 1917.

Jātakamālā: The Jātaka-Mālā or Bodhisattvāvadāna-mālā by Ārya-çūra. Edited by Hendrik Kern. Harvard Oriental Series volume 1. Boston: Harvard University, 1891. Also see Meiland 2009.

Jātakamālā $\bar{a}^{H}$ : Straube, Martin(ed.). 2019. Haribhațta's Jātakamālā. Critically edited from the manuscripts with the help of earlier work by Michael Hahn. Pune Indological Series 11. Pune: Department of Pali, Savitribai Phule Pune University. Also see Khoroche 2017.

Tattvasamgraha: Tattvasangraha of Ācarya [sic] Shāntaraksita with the Commentary 'Pañjikä' of Shri Kamalshïla. Critically Edited by Swami Dwarikadas Shastri. 2 vols. Bauddha Bhāratī Series 1-2. Varanasi: Bauddha Bharati, 1968.

Tridaṇdamālā: Manuscript (probably) not extant, 115 palm-leaf folios (no. 108 skipped), Māgadhī script, ca. 11th century. Read from scans of b/w photographs taken on behalf of Giuseppe Tucci.

Dharmapada (Patna/Saindhava): Cone, Margaret. 1989. "Patna Dharmapada. Part I: Text." Journal of the Pali Text Society 13: 101-217.

Buddhacarita: The Buddhacarita: Or, Acts of the Buddha. Part I-Sanskrit Text. Edited by E.H. Johnston. Panjab University Oriental Publications No. 31. Calcutta: Baptist Mission Press, 1935. Also see Johnston 1936.

Bodhicaryāvatāra: Bodhicaryāvatārapañjikā. Prajñākaramati's commentary of the Bodhicaryāvatāra of Çāntideva. Edited with Indices by Louis de La Vallée Poussin. Bibliotheca Indica 150, fascicles 983, 1031, 1090, 1126, 1139, 1305, 1399. Calcutta: Baptist Mission Press, 1901-1914. Also see La Vallée Poussin 1907.

Manusmrti: Olivelle, Patrick (ed. and tr.). 2005. Manu's Code of Law. A Critical Edition and Translation of the Mānava-Dharmásāstra [sic]. New York: Oxford University Press.

Mahāyānasūtrālaṃkāra: Asañga. Mahāyāna-Sūtrālaṃkāra. Exposé de la doctrine du Grand véhicule selon le système Yogācāra, édité et traduit d'après un manuscrit rapporté du Népal par Sylvain Lévi. Tome I-Texte; Tome II-Traduction, introduction, index. Bibliothèque de l'École des Hautes Études, Sciences historiques et 
philologiques, fascicules 159, 182. Paris: Librairie Honoré Champion Éditeur, 19071911.

Yājñavalkyasmṛti: The Mitākshara with Visvarūpa and Commentaries of Subodhini and Bālambhatti. Edited by S.S. Setlur. Madras: Brahmavadin Press, 1912.

Raghuvamiśa: The Raghuvams'a of Kâlidâsa with The Commentary (the Sanjîvinî̀) of Mallinâth. Edited by Kâs'inâth Pâṇụrang Parab. Revised by Wâsudev Laxman S'âstrî Pans'îkar. Ninth Revised Edition. Bombay: Pândurang Jâwajî, Proprietor of the 'Nirnaya-Sâgar' Press, $1925 \cdot{ }^{114}$

Vimalaprabhā: Vimalaprabhāțīkā of Kalki Śrī Pundarīka on Śrī Laghukālacakratantrarāja by Śrī Mañjuśrīyaśa [vol. ı.]. Critically Edited \& Annotated with Notes by Jagannath Upadhyaya. Bibliotheca Indo-Tibetica Series No. XI. Sarnath: Central Institute of Higher Tibetan Studies, 1986. Also see Newman 1987.

Viṣnudharmottara: Atha Viṣnudharmottaramahāpurāṇaprārambhaḥ. Haidarābāda: Sarvodaya Sāhitya Mandir, no date.

Śikșāsamuccaya: Bendall, Cecil (ed.). 1902. Çikshāsamuccaya. A Compendium of Buddhistic Teachings Compiled by Çāntideva chiefly from earlier Mahāyāna-sūtras. Bibliotheca Buddhica I. St. Petersburg: Imperial Academy of Sciences. Also see Bendall and Rouse 1922.

Subhāṣitaratnakarạ̣dakakathā: See Hahn 1983 b and Zimmermann 1975.

Subhāṣitaratnasaṃdoha: The Subhâshita-Ratna-Sandoha of Amitagati. Edited by Pạ̣dịt Bhavadatta S'âstrî and Kâs'înâth Pândurang Parab. Kâvyamâlâ 82. Bombay: Tukârâm Jâvajî, 1903. Also see Schmidt 1908.

Subhāṣitāvali: The Subhâshitâvali of Vallabhadeva. Edited by Peter Peterson and Pandit Durgâprasâda. Bombay: Education Society's Press, 1886.

Sūktiratnahāra: The Sūktiratnahāra. Edited by K. Sāmbaśiva Sāstrī. Trivandrum Sanskrit Series No. CXLI. Śrī Citrodayamañjarī No. Xxx. Trivandrum: The Superintendent, Government Press, 1938.

Hitopadeśa: See Törzsök 2007.

\section{Secondary Sources}

Acri, Andrea. 2015. "Between Impetus, Fear and Disgust. 'Desire for Emancipation' (Saṃvega) from Early Buddhism to Pātañjala Yoga and Śaiva Siddhānta." Purushottama Bilimoria and Aleksandra Wenta (eds.), Emotions in Indian Thought-Systems. New Delhi: Routledge, pp. 199-227.

Bandurski, Frank. 1994. "Übersicht über die Göttinger Sammlungen der von Rāhula Sānkṛtyāyana in Tibet aufgefundenen buddhistischen Sanskrit-Texte (Funde bud-

114 I thank Csaba Dezső for allowing a preview of the forthcoming edition of the text with Vallabha's commentary (co-authored with Harunaga Isaacson, Dominic Goodall, and Csaba Kiss). 
dhistischer Sanskrit-Handschriften, III)." Frank Bandurski, Bhikkhu Pāsādika, Michael Schmidt, Bangwei Wang (eds.), Untersuchungen zur buddhistischen Literatur. Göttingen: Vandenhoeck \& Ruprecht, pp. 9-126.

Banerjee, Anukul Chandra. 1954. "Subhāṣitaratnakaraṇḍakakathā.” The Indian Historical Quarterly 30: 86-88.

Bechert, Heinz. 1988. "Alte Veḍhas" im Pāli-Kanon, Die metrische Struktur der buddhistischen Bekenntnisformel. Nachrichten der Akademie der Wissenschaften in Göttingen, 1 ; Philologisch-historische Klasse, 4.

Bendall, Cecil and W.H.D. Rouse (trs.). 1922. Śikshā-Samuccaya. A Compendium of Buddhist Doctrine compiled by Śāntideva chiefly from earlier Mahāyāna Sūtras. London: John Murray.

Blackburn, Anne M. 1999. "Looking for the Vinaya: Monastic Discipline in the Practical Canons of the Theravāda." Journal of the International Association of Buddhist Studies 22/2: 281-309.

Chung, Jin-il. 2008. A Survey of the Sanskrit Fragments Corresponding to the Chinese Samyuktāgama/雜阿含經相當 梵文斷片一覽. Tōkyō: 山喜房佛書林 Sankibō Busshorin.

Delhey, Martin. 2015. "The Library at the East Indian Buddhist Monastery of Vikramaśila: an Attempt to Identify Its Himalayan Remains." Manuscript Cultures 8: 224.

Dietz, Siglinde. 200o. "Mātṛcețas Kaliyugaparikathā." Christine Chojnacki, Jens-Uwe Hartmann, and Volker M. Tschannerl (eds.), Vividharatnakarandaka. Festgabe für Adelheid Mette. Indica et Tibetica 37. Swisttal-Odendorf: Indica et Tibetica Verlag, pp. 173-186.

Dimitrov, Dragomir. 2020. The Buddhist Indus Script and Scriptures. On the so-called Bhaikșukī or Saindhavī Script of the Sāmmitīyas and their Canon. Akademie der Wissenschaften und der Literatur, Mainz. Veröffentlichungen der Fächergruppenkommission für Außeuropäische Sprachen und Kulturen. Studien zur Indologie Band 7. Wiesbaden: Harrassowitz Verlag.

Drewes, David Donald. 2006. "Mahāyāna Sūtras and Their Preachers: Rethinking the Nature of a Religious Tradition.” PhD dissertation, University of Virginia.

Drewes, David Donald. 2011. "Dharmabhāṇakas in Early Mahāyāna." Indo-Iranian Journal 54: 331-372.

Durt, Hubert. 2001. "The Vicissitudes of Vāsițthī / Vāsișțhā who became insane due to the loss of her child-From Therīgāthā to Mahāyāna-.”国際仏教学大学院大学研 究紀要 [Journal of the International College for Advanced Buddhist Studies] 4: 27-47 (314-294).

Formigatti, Camillo. 2016. "Walking the Deckle Edge: Scribe or Author? Jayamuni and the Creation of the Nepalese Avadānamālā Literature." Buddhist Studies Review 33/1-2: 101-140. 
Hahn, Michael. 1982. "Kumāralātas Kalpanāmaṇditikā Dṛșṭāntapaṅkti, No. 1. Die Vorzüglichkeit des Buddha." Zentralasiatische Studien 16: 309-336.

Hahn, Michael. 1983a. "Zur Verteilung der Versmaße in der buddhistischen CampūDichtung." Zeitschrift der Deutschen Morgenländischen Gesellschaft, Supplement V, $X X$. Deutscher Orientalistentag vom 24. bis 29. März 1980 in Berlin, Ausgewählte Vorträge, herausgegeben von Fritz Steppat, Wiebaden 1982 (1983), pp. 245-252.

Hahn, Michael. 1983b. Die Subhāṣitaratnakarạ̣dakakathā. Ein spätbuddhistischer Text zur Verdienstlehre. Nachrichten der Akademie der Wissenschaften in Göttingen. I. Philologisch-historische Klasse. Jahrgang 1982 Nr. 9. Göttingen: Vandenhoeck \& Ruprecht.

Hartmann, Jens-Uwe. 2017. "King Prasenajit Bemoans the Death of His Grandmother: A Study of the Manuscript SHT 7185." International Journal of Buddhist Thought \& Culture 27/1: 73-105.

Hartmann, Jens-Uwe. 2020. "Sanskrit Versions of the Agamas: Schools, Regions and Editors." Dhammadinnā (ed.), Research on the Saṃyukta-āgama. Taipei: Dharma Drum Corporation, pp. 359-386.

Hartmann, Jens-Uwe, Kazunobu Matsuda, and Péter-Dániel Szántó. Forthcoming. “The Benefit of Cooperation: Recovering the Śokavinodana ascribed to Aśvaghoṣa”. Felicitation Volume for Ven. Dr. Tampalawela Dharmmaratana.

Heimbel, Jörg. 2013. "The Jo gdan tshogs sde bzhi: An investigation into the History of the Four Monastic Communities in Śākyaśrībhadra's Vinaya Tradition." Franz-Karl Ehrhard and Petra Maurer (eds.), Nepalica-Tibetica. Festgabe for Christoph Cüppers. Band 1. Andiast: International Institute for Tibetan and Buddhist Studies, pp. 187242.

Hinüber, Oskar von. 2020. "The Sagātha-vagga in the Samyutta-nikāya: Formation and Vedic Background.” Dhammadinnā (ed.), Research on the Samyukta-āgama. Taipei: Dharma Drum Corporation, pp. 3-52.

Holmes, John. 1755. The Art of Rhetoric Made Easy: or, The Elements of Oratory. The Second Impression Corrected and Improved. London: C. Hitch \& L. Hawes.

Horiuchi, Toshio. 2019. "Kumāralāta." Jonathan A. Silk, Richard Bowring, Vincent Eltschinger, Michael Radich (eds.), Brill's Encyclopedia of Buddhism. Volume II: Lives. Leiden/Boston: Brill, pp. 293-297.

Huber, Édouard. 1908. Açvaghoṣa Sûtrâlaṃkâra traduit en français sur la version chinoise de Kumârajîva. Paris: Ernest Leroux.

Jackson, David P. 199o. Two Biographies of Śākyaśrībhadra, The Eulogy of Khro phu Lotsā-ba and its "Commentary" by bSod-nams-dpal-bzang-po: Texts and Variants from Two Rare Exemplars Preserved in the Bihar Research Society, Patna. Tibetan and IndoTibetan Studies 4. Stuttgart: Franz Steiner Verlag, 1990.

Jinpa, Thupten and Donald S. Lopez Jr. (trs.). 2014. Gendun Chopel, Grains of Gold. Tales of a Cosmopolitan Traveler. Chicago and London: The University of Chicago Press. 
Johnston, Edward Hamilton. 1936. The Buddhacarita Or, Acts of the Buddha. Part II: Cantos i to xiv translated from the original Sanskrit supplemented by the Tibetan version together with an introduction and notes. Panjab University Oriental Publications No. 32. Calcutta: Baptist Mission Press.

Johnston, Edward Hamilton. 1939. "The Tridạ̣damālā of Aśvaghoṣa." Journal of the Bihar and Orissa Research Society 25: 11-14.

Kafle, Nirajan. 2013. "The Lingodbhava Myth in Early Śaiva Sources." Nina Mirnig, PéterDániel Szántó, Michael Williams (eds.), Pușpikā: Tracing Ancient India Through Texts and Traditions: Contributions to Current Research in Indology Volume 1. Oxford: Oxbow Books, pp. 241-264.

Kane, Pandurang Vaman. 1953. History of Dharmaśāstra (Ancient and Mediaeval Religious and Civil Law in India). Vol. IV (Pātaka, Prāyaścitta, Karmavipāka, Antyești, Āśauca, Śuddhi, Śrāddha and Tìrthayātrā). Poona: Bhandarkar Oriental Research Institute.

Kano, Kazuo. 2016. "The Transmission of Sanskrit Manuscripts from India to Tibet: The Case of a Manuscript Collection in the Possession of Atiśa Dīpaṃkaraśrīināāna (9801054)." Carmen Meinert (ed.), Transfer of Buddhism Across Central Asian Networks (7th to 13th Centuries). Leiden/Boston: Brill, pp. 82-117.

Karashima, Seishi. 2018. "Ajita and Maitreya: More evidence of the early Mahāyāna scriptures' origins from the Mahāsāṃghikas and a clue as to the school-affiliation of the Kanaganahalli-stūpa." Annual Report of The International Research Institute for Advanced Buddhology at Soka University 21: 181-196.

Khoroche, Peter. 2017. Once a Peacock, Once an Actress. Twenty-Four Lives of the Bodhisattva from Haribhațta's Jātakamālā. Chicago and London: The University of Chicago Press.

La Vallée Poussin, Louis de. 1907. Bodhicaryāvatāra. Introduction à la pratique des futurs bouddhas. Poéme de Çāntideva. Extrait de la Revue d'histoire et de littérature religieuses, t. X, XI et XII, 1905, 1906, 1907. Paris: Librairie Bloud et $C^{\text {ie }}$.

Luo, Zhao [罗照]. n.d. [circa 1982]. 布达拉宫罗布林卡所藏贝叶经目录 [Budala gong, Luobulinka suocang beiyejing mulu; Catalogue of the Sanskrit Holdings of the Potala and Norbulingka Palaces.] Unpublished.

Masset, Danièle. 2005. Stances des Therī (Therīgāthā). Pali Text Society Translation Series, No. 51. Oxford: The Pali Text Society.

Matsuda, Kazunobu [松田 和信]. 2019. 三啓集 (Tridaṇḍamālā) における勝義空経 とブッダチャリ夕 [“The Paramārthaśūnyatā-sūtra and Aśvaghoṣa’s Buddhacarita Canto 16 in the Tridandamālā."] 印度學佛敎學研究 [Journal of Indian and Buddhist Studies] 68/1: 1-11.

Matsuda, Kazunobu [松田 和信]. 2020a. ブッダチャリ夕第15章「初転法輪」一梵 文テキストと和訳—[“Sanskrit Text and Japanese Translation of the Buddhacarita Canto 15 “Dharmacakrapravartana."”] 佛教大学 仏教学会紀要 [The Bulletin of the Association of Buddhist Studies, Bukkyo University] 25: 27-44. 
Matsuda, Kazunobu [松田 和信]. 202ob. 大智度論におけるアシュヴァゴーシャ一 如来十号論に埋め込まれた荘㛜経論—[“Aśvaghoṣa's Lost Stanzas Included in the *Mahāprajñāpāramitopadeśa."] 印度學佛敎學研究 [Journal of Indian and Buddhist Studies] 69/1: 53-61 (436-428).

Matsuda, Kazunobu [松田 和信]. 2021. 不净観を説く中阿含139経一三啓集か ら回収された梵文テキストと和訳—[“Sanskrit Text and Japanese Translation of the Madhyama-Āgama 139 ( ${ }^{*}$ Śivapathikā-sūtra) Based on the Tridandamālā Manuscript"] 佛教大学 仏教学会紀要 [The Bulletin of the Association of Buddhist Studies, Bukkyo University] 26: 63-81.

Meiland, Justin. 2009. Garland of the Buddha's Past Lives (Volume 1). Clay Sanskrit Library 8. JJC Foundation \& New York University Press.

Mirashi, Vasudev Vishnu. 1961. "A Note on the Subhāshitaratnakaraṇḍakakathā of Āryasuura." The Adyar Literary Bulletin 25: 304-307.

Nalesini, Oscar. 2008. "Assembling Loose Pages, Gathering Fragments of the Past: Giuseppe Tucci and His Wanderings Throughout Tibet and the Himalayas, 19261954." Francesco Sferra (ed.), Sanskrit Texts from Giuseppe Tucci's Collection, Part I. Manuscripta Buddhica 1. Roma: Istituto Italiano per l'Africa e l'Oriente, pp. 79112.

Newman, John Ronald. 1987. "The outer Wheel of Time: Vajrayāna Buddhist cosmology in the Kālacakra Tantra." PhD dissertation, The University of Wisconsin, Madison.

Norman, Kenneth Roy. 1992. The Group of Discourses (Sutta-Nipāta) Volume II. Revised translation with introduction and notes. Oxford: The Pali Text Society.

Norman, Kenneth Roy. 2008. "Why Are the Four Noble Truths Called "Noble"?" Ananda: Essays in Honour of Ananda W.P. Guruge = K.R. Norman Collected Papers no. 90, vol. IV: 171-174.

Okada, Mamiko. 1993. Dvāvimśatyavadānakathā: ein mittelalterlicher buddhistischer Text zur Spendenfrömmigkeit. Indica et Tibetica 24. Bonn: Indica et Tibetica Verlag.

Olivelle, Patrick. 2013. King, Governance, and Law in Ancient India. Kauțilya's Arthaśāstra. A New Annotated Translation. New York: Oxford University Press.

Saito, Naoki. 2005. Das Kompendium der Moralischen Vollkommenheiten. Vairocanarakṣitas tibetische Übertragung von Āryaśūras Pāramitāsamāsa samt Neuausgabe des Sanskrittextes. Indica et Tibetica 38. Marburg: Indica et Tibetica Verlag.

Sānkṛtyāyana, Rāhula (Tripițakâcharya Rāhula Sāṅkṛityāyana). 1935. "Sanskrit Palmleaf Mss. in Tibet." Journal of the Bihar and Orissa Research Society 21: 21-43.

Sānkṛtyāyana, Rāhula (Rev. Rāhula Sānkṛ̂tyāyana). 1938. "Search for Sanskrit Mss. in Tibet." Journal of the Bihar and Orissa Research Society 24: 137-163.

Sānkṛtyāyana, Rāhula. 1994 [1998]. Merī Jōvan Yātrā. ed. by Kamalā Sānkṛ̂tyāyana et al. Rāhul Vāngmaya Part I: vol. 2. New Delhi: Rādhākṛ̣ṇa Prakāśan.

Schmidt, Richard. 1908. Amitagati’s Subhāṣitasaṃdoha, Sanskrit und Deutsch. Sonder- 
abdruck aus Band LIX und LXI der Zeitschrift der Deutschen Morgenländischen Gesellschaft, 1905 und 1907. Leipzig: in Kommission bei F.A. Brockhaus.

Schneider, Johannes. 2014. Eine buddhistische Kritik der indischen Götter. Śaṃkarasvāmins Devātiśayastotra mit Prajñāvarman's Kommentar. Wien: Arbeitskreis für Tibetische und Buddhistische Studien.

Sferra, Francesco. 2008. "Sanskrit Texts from Giuseppe Tucci's Collection." Francesco Sferra (ed.), Sanskrit Texts from Giuseppe Tucci's Collection, Part I. Manuscripta Buddhica 1. Roma: Istituto Italiano per l'Africa e l'Oriente, pp. 15-78.

Silk, Jonathan Alan. 1994. "The origins and early history of the Mahāratnakūța tradition of Mahāyāna Buddhism with a study of the Ratnarāśisūtra and related materials." Vols. I-II. PhD dissertation, University of Michigan.

Silk, Jonathan Alan. 2015. "Canonicity." Jonathan A. Silk et al. (eds.), Brill's Encyclopedia of Buddhism. Volume I: Literature and Languages. Handbook of Oriental Studies/Handbuch der Orientalistik, Section Two: India, volume 29/1. Brill: Leiden/ Boston, pp. $5^{-37}$.

Skilling, Peter. 2006. "Daśabalaśrīmitra on the Buddhology of the Sāṃmitīyas." Nagoya Studies in Indian Culture and Buddhism: Saṃbhāṣā 25: 99-123.

Skilling, Peter. 1999. "A Buddhist Inscription from Go Xoai, Southern Vietnam and Notes towards a Classification of ye dharmā Inscriptions." 8o pī śāstrācāry dr. prahsert ṇa nagara: ruam pada khvam vijākāra dan charük lae ekasāraporāṇa 80 ปี ศาสตราจารย์ ดร.ประเสริฐ ณ นคร : รวมบทความวิชาการด้านจารึกและเอกสารโบราณ [8o Years: A Collection of Articles on Epigraphy and Ancient Documents Published on the Occasion of the Celebration of the 8oth Birthday of Prof. Dr. Prasert Na Nagara, Bangkok 21 March 2542]. Bangkok, pp. 171-187.

Steiner, Roland. 2019. "Āryaśūra." Jonathan A. Silk, Richard Bowring, Vincent Eltschinger, Michael Radich (eds.), Brill's Encyclopedia of Buddhism. Volume II: Lives. Leiden/Boston: Brill, pp. 70-72.

Sujato, Bhikkhu. 2005 [2012]. A History of Mindfulness. How insight worsted tranquillity in the Satipațthāna Sutta. First edition: The Corporate Body of the Buddha Education Foundation, Taiwan. Second, revised edition: Santipada.

Tournier, Vincent. Forthcoming. "A 4th/5th-Century sütra of the Sammitìya Canon? On the So-Called 'Continental Pāli' Inscription from Devnimori.” Claudio Cicuzza (ed.), Proceedings of the Third International Pali Studies Week-Paris 2018. Bangkok and Lumbini: Fragile Palm Leaf Foundation and Lumbini International Research Institute.

Tucci, Giuseppe. 1949. Tibetan Painted Scrolls. Volume I. Roma: La Libreria Dello Stato. Tucci, Giuseppe. 1956. チベット及びネポールにおいて新たに発見せられた仏教典 籍について “Buddhist Literatures Newly Recovered in Tibet and Nepal." [Japanese translation of an English paper now untraced] 大谷學報 The Otani Gakuho (The Journal of Buddhology and Cultural Science) 36/1: 1-16. 
Törzsök, Judit. 2007. Friendly Advice by Naráyana \& King Víkrama’s Adventures. The Clay Sanskrit Library. New York: New York University Press and the JJC Foundation.

van der Kuijp, Leonard. 1994. “On the Lives of Śākyaśrībhadra (?-?1225).” Journal of the American Oriental Society 114: 599-616.

Vinītā, Bhikṣuṇī (Vinita Tseng). 2010. A unique collection of twenty Sūtras in a Sanskrit manuscript from the Potala. 2 vols. Sanskrit Texts from the Tibetan Autonomous Region no. 7. Beijing \& Vienna: China Tibetology Publishing House \& Austrian Academy of Sciences Press.

Wang, Sen [王森]. 2006. [Catalogue of the Sanskrit Manuscripts Once Kept at the Palace of the Minorities of Beijing]. Published as an appendix to Haiyan Hu-von Hinüber, "Some Remarks on the Sanskrit Manuscript of the Mūlasarvāstivāda-Prātimokṣasūtra Found in Tibet." Jaina-Itihāsa-Ratna. Festschrift für Gustav Roth zum 90 Geburtstag, edited by Ute Hüsken et al., 297-334. Marburg: Indica et Tibetica Verlag.

Willemen, Charles. 1999. The Scriptural Text: Verses of the Doctrine, with Parables. Translated from the Chinese of Fa-li and Fa-chü (Taishō Volume 4, Number 211). BDK English Tripițaka 1O-II. Berkeley: Numata Center for Buddhist Translation and Research.

Yamasaki, Kazuho. 2018. "On the Author of the Subhāṣitaratnakarandakakathā." 印度 學佛敉學研究 [Journal of Indian and Buddhist Studies] 66/3: 82-88 [1056-1062].

Zimmermann, Heinz. 1975. Die Subhāṣita-ratna-karạ̣daka-kathā (dem Āryaśūra zugeschrieben) und ihre tibetanische Übersetzung: ein Vergleich zur Darlegung der Irrtumsrisiken bei der Auswertung tibetanischer Übersetzungen. Freiburger Beiträge zur Indologie 8. Wiesbaden: Harrassowitz.

\section{Acknowledgments}

My thanks first and foremost to Harunaga Isaacson for his illuminating comments and emendations. I am very grateful to Ralph H. Craig III, Csaba Dezső, Dragomir Dimitrov, Rafal Felbur, Csilla Gábor, Xiaoqiang Meng, Richard Salomon, Jonathan Silk, and Vincent Tournier for the many ways in which they kindly helped me. All remaining errors are mine alone. This work was supported by the European Research Council (ERC) under the Horizon 2020 program (Advanced Grant agreement No 741884).

\section{Dedication}

This study is dedicated to the memory of Stefano Zacchetti (1968-2020), scholar, humanist, mentor, teacher, and friend. I must confess that I have learnt 
nothing from the sermons of our anonymous homiletician: the untimely death of our dear friend still fills me with infinite sadness and I find little solace in the treasured memories of the times spent in his company. The fact that he would have had insightful comments on this study is the very least of our losses, but for me it is a missed opportunity I will always regret. 